\title{
Potential Role of Plant Extracts and Phytochemicals Against Foodborne Pathogens
}

\author{
Farhat Ullah ${ }^{1}$, Muhammad Ayaz ${ }^{1, *}$, Abdul Sadiq ${ }^{1}$, Farman Ullah ${ }^{2}$, Ishtiaq Hussain ${ }^{3}$, \\ Muhammad Shahid ${ }^{4}$, Zhanibek Yessimbekov ${ }^{5}$, Anjana Adhikari-Devkota ${ }^{6}$ and \\ Hari Prasad Devkota $6,7, *$ (iD \\ 1 Department of Pharmacy, University of Malakand, Khyber Pakhtunkhwa (KP) 18000, Pakistan; \\ drfarhatullah@uom.edu.pk (F.U.); a.sadiq@uom.edu.pk (A.S.) \\ 2 Department of Pharmacy, Kohat University of Science and Technology (KUST), Kohat 26000, \\ Khyber Pakhtunkhwa, Pakistan; farmanullah@kust.edu.pk \\ 3 Department of Pharmaceutical Sciences, Abbottabad University of Science and Technology, \\ Abbottabad 22010, Pakistan; ishtiaqdr025@gmail.com \\ 4 Department of Pharmacy, Sarhad University of Science and Information Technology, Peshawar KPK 25000, \\ Pakistan; Shahidsalim_2002@hotmail.com \\ 5 Shakarim State University of Semey, Semey 071412, Kazakhstan; zyessimbekov@semgu.kz \\ 6 Graduate School of Pharmaceutical Sciences, Kumamoto University, 5-1 Oe-honmachi, Kumamoto 862-0973, \\ Japan; anjana@kumamoto-u.ac.jp \\ 7 Program for Leading Graduate Schools, Health Life Sciences: Interdisciplinary and Glocal Oriendted (HIGO) \\ Program, Kumamoto University, 5-1 Oe-honmachi, Kumamoto 862-0973, Japan \\ * Correspondence: mayaz@uom.edu.pk (M.A.); devkotah@kumamoto-u.ac.jp (H.P.D.)
}

Received: 26 May 2020; Accepted: 29 June 2020; Published: 2 July 2020

\begin{abstract}
Foodborne diseases are one of the major causes of morbidity and mortality, especially in low-income countries with poor sanitation and inadequate healthcare facilities. The foremost bacterial pathogens responsible for global outbreaks include Salmonella species, Campylobacter jejuni, Escherichia coli, Shigella sp., Vibrio, Listeria monocytogenes and Clostridium botulinum. Among the viral and parasitic pathogens, norovirus, hepatitis A virus, Giardia lamblia, Trichinella spiralis, Toxoplasma and Entamoeba histolytica are commonly associated with foodborne diseases. The toxins produced by Staphylococcus aureus, Bacillus cereus and Clostridium perfringens also cause these infections. The currently available therapies for these infections are associated with various limited efficacy, high cost and side-effects. There is an urgent need for effective alternative therapies for the prevention and treatment of foodborne diseases. Several plant extracts and phytochemicals were found to be highly effective to control the growth of these pathogens causing foodborne infections in in vitro systems. The present review attempts to provide comprehensive scientific information on major foodborne pathogens and the potential role of phytochemicals in the prevention and treatment of these infections. Further detailed studies are necessary to evaluate the activities of these extracts and phytochemicals along with their mechanism of action using in vivo models.
\end{abstract}

Keywords: foodborne diseases; giardiasis; herbal drugs; ethnobotany; toxoplasmosis

\section{Introduction}

Foodborne diseases are caused by consumption of microbial contaminated foods, herbs and beverages as well as hazardous chemicals including heavy metals, mycotoxins, bacterial toxins as well as fermentation byproducts like biogenic amines and ethyl carbamate [1-3]. Most these foodborne diseases are caused by pathogenic bacteria, viruses and parasites and are of global public health concern [4]. Each year about 600 million people are affected by foodborne diseases worldwide and 
about 420,000 people die due to these illnesses [5-8]. The most common symptoms associated with pathogens-induced foodborne diseases are vomiting, abdominal pain, diarrhea, fever and chills that may progress to severe complications such as life-threatening dehydration and hemolytic uremic syndrome (HUS) [9]. The bacterial-induced foodborne diseases are caused by infections with Salmonella, Campylobacter spp., Escherichia coli, Shigella, Vibrio, Listeria monocytogenes and Clostridium botulinum and Clostridium perfringens [4]. The commonly reported viruses are Norovirus and Hepatitis A, while the parasites involved are Cryptosporidium spp, Giardia lamblia, Trichinella spiralis, Cyclospora spp, Toxoplasma canis and Entamoeba histolytica [10,11] The toxins produced by Staphylococcus aureus, Bacillus cereus and Clostridium perfringens also prompt this debilitating disease [12]. Recently, there is a dramatic increase in the outbreak of foodborne disease, part of which is due to the emergence of pathogens resistance against current therapies and decontamination strategies [13]. Theses pathogens use food stuff as carrier to get transferred from one host to another one [14]. The diseases caused by these pathogens are a major public health concern and globally produce a social and economic impact.

The proper handling, use of cold chain and addition of chemical preservatives are currently the mainstay to ensure the preservation and safety of food materials. However, the use of synthetic preservatives is associated with a high occurrence of side-effects, thereby raising the demand for the use of natural preservatives $[15,16]$. The main treatment options for foodborne diseases are systematic treatments like antidiarrheal and antiemetic medications, use of oral rehydration salts and the use of antibiotics [17]. However, the emergence of multi drug-resistant (MDR pathogens) is another global issue that requires the discovery of alternative antimicrobial agents [18-20].

Medicinal plants play a vital role in the treatment and prevention of various diseases and their promotion and there is growing interest in the search for new drugs from natural resources [21-26]. People living in many developing countries in Asia and Africa are mostly dependent on traditional medicines for healing purposes due to their limited access to modern medical facilities. They also have more cases of foodborne diseases because of their poor hygiene and exposure to contaminated drinking water and food materials $[27,28]$. Various studies have regularly reported the antimicrobial activities of traditional medicines from this part of the world. Medicinal plants offer a substantial opportunity as they contain various bioactive chemical constituents (phytochemicals) that can act as antimicrobial agents. Natural products are also reported to act as synergists along with many modern drugs to combat MDR pathogens [29]. Thus, the exploration of these natural antimicrobials is a hope to curtail foodborne diseases. Traditional medicines have long been used for treating diseases caused by foodborne pathogens and various studies have shown their efficacy in the management of foodborne diseases [30]. Recently, there is a greater interest in the naturally occurring preservatives due to the side-effects associated with the use of artificial preservatives in foodstuffs. Crude plant materials including extracts, essential oils and isolated components have been extensively evaluated to prevent the invasion of pathogens responsible for food spoilage and therefore may limit the spread of foodborne infections [31].

Plants/plant-derived products inhibit/modify the growth of bacteria by several mechanisms. These may include, inhibiting the adherence of the pathogen to host cells [32], causing loss of osmoregulation of microbe and loss of transmembrane electrochemical gradient, increasing NO production thus causing lethal action [33], inhibition of synthesis of the cell wall, proteins and nucleic acids of the pathogen [34]. This review summarizes the therapeutic effectiveness of medicinal plants and isolated natural compounds against pathogens implicated in foodborne infections.

\section{Materials and Methods}

Published literature related to the role of phytochemicals in foodborne infections was collected using different search engines like PubMed, Google Scholar, SciFinder, Scopus, Web of Science, EBSCO, PROTA and JSTOR. Only in-depth, well designed (having control groups) studies reporting mechanistic results and published in journals of good quality were included in the manuscript. 


\section{Plant Extracts and Phytochemicals against Bacteria Causing Foodborne Diseases}

\subsection{Campylobacter Species}

Campylobacter jejuni is a Gram-negative, non-spore-forming and non-fermenting bacteria. It is one of the most common causes of foodborne diseases in the US and Europe. Humans are usually infected by the ingestion of contaminated food, milk, water or interaction with animals [35]. Globally, about 9.6 million people are infected by $C$. jejuni annually [36]. For the treatment of $C$. jejuni infection, tetracyclines and fluoroquinolones are the drugs of choice; however, these days they are associated with a high degree of antibiotic-resistance [37,38]. Alternatively, phytochemicals can be utilized as they have the potential to combat foodborne diseases caused by C. jejuni. Dholvitayakhun et al. reported the inhibitory activity of extracts of Adenanthera pavonina L., Moringa oleifera Lam. and Annona squamosa L. against $C$. jejuni [39]. In these plants, among the flavonoids, kaempferol, quercetin and rutin are present which possess strong antimicrobial properties [40]. Mammea africana Sabine is used traditionally for the treatment of infections, stomach pain and skin ailments in Africa [41]. A coumarin, mammea A/AA was isolated by Canning et al. from Mammea africana and evaluated its activity against $C$. jejuni. It was found to be very potent with a minimum inhibitory concentration (MIC) value of $0.25 \mu \mathrm{g} / \mathrm{mL}$ [42]. Castillo et al. evaluated 28 plants against $C$. jejuni, out of which 21 were active. Of these 21 active plants, 4 plants including Artemisia ludoviciana Nutt., Acacia farnesiana (L.) Willd. Opuntia ficus-indica (L.) Mill. and Cynara scolymus L. were most potent having minimal bactericidal concentration (MBC) values of $0.5,0.3,0.4$ and $2 \mathrm{mg} / \mathrm{mL}$, respectively. They also tested the anti-adherence activity of these 4 plants against $C$. jejuni, as adherence of the microbe to mucosal cells is important for its virulence. The results proved that extracts were able to inhibit the attachment of C. jejuni [32]. Another mechanism of $C$. jejuni pathogenicity is cell lysis, entry into the host cell and production of a virulent cytotoxin, cytolethal distending toxin (CDT) [43]. Extracts of A. ludoviciana and A. farnesiana were shown to prevent the production of CDT along with a decrease in cytoplasmic $\mathrm{pH}$ and cellular ATP concentration and damages the bacterial cell membrane [44]. Moreover, motility also contributes to the virulence of $C$. jejuni. The subinhibitory concentrations of natural compounds, i.e., carvacrol $(0.002 \%)$, trans-cinnamaldehyde $(0.01 \%)$ and eugenol $0.01 \%)$ prominently decrease the motility of $C$. jejuni. Furthermore, these natural compounds also reduce other virulence potentials of this pathogen [45].

Several researchers have reported the potential antibacterial activity of essential oils (EO) of various plants against $C$. jejuni that are commonly used in the traditional system of medicine. These plants include Syzygium aromaticum (L.) Merr. \& L.M.Perry [46,47], Citrus limon (L.) Osbeck and Citrus bergamia Risso [48], tea tree oil, Leptospermum oil [49], coriander (Coriandrum sativum L.) [50], Daucus carota L. [51], Cuminum cyminum L. [52], garlic (Allium sativum L.) [53], clove (Syzygium aromaticum), thyme (Thymus vulgaris L.) [54], eucalyptus (Eucalyptus globulus Labill.), sage (Salvia officinalis L.), rosemary (Rosmarinus officinalis L.), juniper (Juniperus communis L.), lavender (Lavandula officinalis Chaix), Myrtus communis L., Laurus nobilis L., pine oil (Pinus brutia) [55], Juniperus excelsa M.Bieb. [56], Inula helenium L [52], marigold (Calendula officinalis L.), ginger (Zingiber officinale L.), patchouli (Pogostemon cablin), gardenia (Gardenia jasminoides (Blanco) Benth.), cedarwood (Cedrus atlantica (Endl.) Manetti ex Carrière), carrot seed (Daucus carota L.), celery seed (Apium graveolens L.), mugwort (Artemisia vulgaris L.), spikenard (Nardostachys jatamansi (D.Don) DC.), orange bitter oils (Citrus $\mathrm{x}$ aurantium subsp. amara (Link) Engl.), etc [47].

Terminalia macroptera Guill. \& Perr. has been used for treating various infectious diseases in West Africa. Silva et al. subjected 100 clinical isolates of $C$. jejuni to the ethanolic extract of T. macroptera and recorded a MIC value as low as $6.25 \mu \mathrm{g} / \mathrm{mL}$, which was similar to that of co-trimoxazole, used as the positive control, therefore suggests a therapeutic potential of T. macroptera in foodborne disease caused by C. jejuni [57]. In South Africa, Samie et al. conducted a study on clinically isolated C. jejuni from stool samples $(n=110)$ to find a complementary therapeutic remedy for this infection. They tested extracts of 18 plants i.e., Annona sp., Bauhinia galpinii N.E.Br., Bridelia micrantha (Hochst.) Baill., 
Carissa edulis (Forssk.) Vahl, Cissampelos torulosa E.Mey. ex Harv. \& Sond., Elaeodendron transvaalensis (Burtt Davy) R.H.Archer, Ficus sycomorus L., Lippia javanica (Burm.f.) Spreng., Momordica balsamina L., Mucuna coriacea Baker, Peltophorum africanum Sond., Pouzolzia mixta Solms, Pterocarpus angolensis DC, Rhoicissus tridentate (L.f.) Wild \& R.B.Drumm., Sida alba L., Syzygium cordatum Hochst. ex Krauss, Ximenia caffra Sond. and Zornia milneana Mohlenbr. on these isolated bacterial strain. All the extracts were active, but potent activity was observed with the extracts of $P$. angolensis and L. javanica having an MIC of $90 \mu \mathrm{g} / \mathrm{mL}$ [58]. The extract of Cryptolepis sanguinolenta (Lindl.) is used traditionally for treating different infections in Guinea Bissau. An alkaloid cryptolepine has been isolated from this plant. When tested on a collection of 106 clinical strains of $C$. jejuni by Paulo et al. in Portugal, it was found to be very effective. They recorded $\mathrm{MIC}_{50}$ of this alkaloid was equal to that of ampicillin in their study [59]. Jarriyawattanachaikul et al. in Thailand, evaluated 26 Thai plants against $C$. jejuni in search of complementary therapy for infection caused by this bacterium. They found 7 active plants, i.e., taew kaao (Cratoxylum formosum (Jacq.) Benth. \& Hook.f. ex Dyer), golden shower (Cassia fistula L.), mangosteen (Garcinia mangostana L.), ginger (Zingiber officinale Roscoe), garlic (Allium sativum L.), onion (Allium cepa L.) and shallot (Allium ascalonicum L.), among which C. formosum possesses the strongest antibacterial activity as observed from its MIC of $0.3 \mathrm{mg} / \mathrm{mL}$ [60]. A traditional beverage, kombucha, showed strong activity against $C$. jejuni [61]. Black and green tea, which are the most widely consumed beverages in the world also have confirmed antibacterial propensity against C. jejuni [62]. Aslim et al. have obtained convincing results of the essential oil of Origanum minutiflorum O.Schwarz \& P.H.Davis against a ciprofloxacin-resistant strain of $C$. jejuni. [63]. Many Australians plants possess antimicrobial properties and have been utilized by the native populations for centuries as traditional medicines for GIT diseases. In a study by Kurekci et al., 109 plants from Australia were tested against $C$. jejuni. Most of these plants were active as their MICs fall between 32 and $1024 \mu \mathrm{g} / \mathrm{mL}$. Eucalyptus occidentalis Endl. was the most active plant reported with MIC of $32 \mu \mathrm{g} / \mathrm{mL}$ [64].

\subsection{Salmonella}

Salmonella is a rod-shaped, Gram-negative, motile, non-spore-forming bacteria belonging to family Enterobacteriaceae. Members of this genus are facultative anaerobes, oxidase negative and catalase-positive bacteria [65]. Salmonella species exist everywhere in nature, however, the gastrointestinal tracts of mammals, reptiles, birds and insects and environment polluted with humans or animals' excreta are the main reservoirs [66]. Their characteristic to survive and grow over a wide range of temperature $\left(2-54^{\circ} \mathrm{C}\right)$ and $\mathrm{pH}(3.6-9.6)$ makes them difficult to control [67]. Salmonellosis, which is an infection caused by Salmonella species is one of the leading causes of foodborne diseases [68]. Transmission to humans occurs via consumption of contaminated food, mostly of animal origins such as milk, eggs and meat. The antibiotics ampicillin, chloramphenicol and co-trimoxazole were once considered as the mainstay treatments for Salmonella infection but are largely replaced by fluoroquinolones due to bacterial resistance to antibiotics. Recently, resistance to fluoroquinolones has also emerged [69], thus necessitating the use of traditional medicines for Salmonella infections.

Extracts of Acacia nilotica L. have been tested against Salmonella species in which the extract disrupted the cell wall of bacteria with consequent release of electrolytes and cellular constituents [70]. Another study conducted by Khan et al. in India has also confirmed the potential use of A. nilotica against Salmonella. They recorded MIC as $9.75 \mu \mathrm{g} / \mathrm{mL}$ in their study [71]. Sugarcane bagasse has also been tested for anti-Salmonella activity. It was found to be bacteriostatic and caused leakage of electrolytes [72]. In South Africa, herbs are used as traditional medicine for the treatment of GIT disorders, e.g., stomach pain, diarrhea, etc. Bisi-Johnson et al. conducted a comprehensive study to scientifically prove the effectiveness of traditional plants for treating Salmonella infection. These plants include Aloe arborescens Mill., Acacia mearnsii De Wild., Aloe striata Haw., Eucomis autumnalis (Mill.) Chitt., E. comosa (Houtt.) Wehrh., Cyathula uncinulata (Schrad.) Schinz, Hydnora africana Thunb., Hermbstaedtia odorata (Bur ch. ex Moq.) T. Cooke, Hypoxis latifolia Wight, Psidium guajava L., Pelargonium sidoides DC., Schizocarphus nervosus (Burch.) van der Merwe. Although most of the studied plants 
were active in the study, but A. arborescens, A. striata, C. uncinulata, E. autumnalis, E. comosa and P. guajava were particularly potent. The Salmonella species used in this study was extended spectrum beta-lactamase positive (ESBL) [73]. In another study from South Africa, the potent antibacterial activity of medicinal was been reported which include Hypericum roeperianum Schimp. ex A.Rich., Cremaspora triflora (Thonn.) K.Schum., Heteromorpha arborescens (Spreng.) Cham. \& Schltdl., Pittosporum viridiflorum Sims, Bolusanthus speciosus (Bolus) Harms, Calpurnia aurea (Aiton) Benth., Maesa lanceolata Forssk., Elaeodendron croceum (Thunb.) DC. and Morus mesozygia Stapf. All the plant extracts used were active against Salmonella isolates, but Cremaspora triflora and Maesa lanceolata were very potent having MIC of 0.12 and $0.13 \mathrm{mg} / \mathrm{mL}$, respectively [74]. Entada abyssinica A.Rich. is traditionally used in bacterial infections of the gastrointestinal tract (GIT). A total of 8 compounds were isolated from this plant including flavonoids and terpenoids and tested for anti-Salmonella activity. Entadanin was found to be the most potent compound having a MIC of $1.56 \mu \mathrm{g} / \mathrm{mL}$ [75]. Leea indica (Burm. f.) Merr. from Saudi Arabia [76], Leea indica, Sclerocarya birrea (A.Rich.) Hochst. from South Africa [77,78], Lawsonia inermis L. from Pakistan [79], Rhus succedanea L. from India [80], Achillea clavennae L., Achillea holosericea Sm., Achillea lingulata Waldst. \& Kit. and Achillea millefolium L. from Japan [81], Butomus umbellatus L., Polygonum amphibium L. and two species of the genus Sparganium (S. erectum L. and S. emersum Rehmann) from Turkey [82], Spathodea campanulata P.Beauv., Ficus bubu Warb., Carica papaya L., Cissus aralioides (Welw. ex Baker) Planch., Piptadeniastrum africana (Hook.f.) Brenan, Hilleria latifolia (Lam.) H.Walter, Gladiolus gregarious Welw. ex Baker and Phyllanthus muellerianus (Kuntze) Exell from Cameroon [83,84], persimmon (Diospyros lotus L.), guava (Psidium guajava L.), sweetsop (Annona squamosal Linn.) and Cichorium intybus L. from China [85,86], Anisophyllea laurina R. Br ex Sabine from Guinea [87], Sambucus australis Cham. \& Schltdl. from Brazil [88], Terminalia avicennioides Guill. \& Perr., Momordica balsamina, Combretum paniculatum Vent., Trema guineensis (Schum. \& Thonn.) Ficalho, Morinda lucida Benth. and Ocimum gratissimum L. from Nigeria [89] were reported to have strong antibacterial activity against Salmonella species. It has been observed that EO disrupt and increase the permeability of bacterial cell walls, therefore causing the release of intracellular organelles and proteins. The end result is inactivation and death of the microbes as reviewed by Franklyne et al. [90]. Most of the spices contain EO and consumption of spices has additional health benefits. The common spice ingredients like black pepper, fennel, coriander, cardamom are rich in EO [91].

Biosynthesized nanoparticles of metals (metals + natural materials) are frequently reported to have enhanced pharmacological activities. A newly emerged concept is nano-antibiotics [92], which use plants mediated biogenic nanoparticles with improved antimicrobial, chemotherapeutic and biologic properties $[93,94]$. Using this approach, several metals are reduced using aqueous extracts of medicinal plants [95] and then used as antimicrobial agents with advanced drug delivery and therapeutic outcomes [96]. Silver (Ag) nanoparticles of aqueous leaf extract of Eupatorium odoratum L. were shown to have high anti-Salmonella activities than the aqueous leaf extract of E. odoratum and also $\mathrm{AgNO}_{3}$ [97]. Silver nanoparticles using the aqueous leaf extracts of Lippia citriodora (Palau) Kunth have also been proved to be active against Salmonella species [98]. Other authors have also applied nanoparticles of phytoconstituents against Salmonella and obtained potent antibacterial activity [99-101].

\subsection{Escherichia coli}

Escherichia coli (E. coli), Gram-negative rods, belongs to Enterobacteriaceae family. They represent a vital part of human intestinal normal flora [102]. Enterohemorrhagic E. coli (EHEC) produces verotoxin which causes gastrointestinal cramps and diarrhea [103]. The most prevalent serotype O157:H7 which can lead to HUS followed by neurological disorders and kidney failure. Consumption of unhygienic foods including meat, unprocessed milk, fruits, vegetables can transmit the microbes [104]. This important pathogen involved in foodborne diseases was once highly responsive to fluoroquinolones and beta-lactams, but now is resistant to these antibiotics [105]. Therefore, alternative strategies, e.g., traditional medicines as such and compounds derived from such sources are used to treat foodborne diseases caused by E. coli. Acacia nilotica (L.) Del has been found to disintegrate the cell wall of E. coli and 
release nucleic acids, proteins with a reduction in viable cell growth [70]. In an in vitro study by Elisha et al., nine plants (Hypericum roeperianum Schimp. ex A.Rich., Cremaspora triflora (Thonn.) K.Schum., Heteromorpha arborescens (Spreng.) Cham. \& Schltdl., Pittosporum viridiflorum Sims, Bolusanthus speciosus (Bolus) Harms, Calpurnia aurea (Aiton) Benth., Maesa lanceolata Forssk., Elaeodendron croceum (Thunb.) DC. and Morus mesozygia Stapf) were selected for antibacterial activity against E. coli. All were found to be active against $E$. coli and thus could be used in the therapeutic management of $E$. coli infection. The lowest MIC was observed for Maesa lanceolata as $0.04 \mathrm{mg} / \mathrm{mL}$ [74]. Wasabia japonica (Miq.) Matsum. is an edible plant that grows at shady, humid and cool places in Japan, China, New Zealand and Korea, and possesses many medicinal properties. This plant inhibits E. coli strain O157:H7 which is widely responsible for diarrhea in foodborne diseases [106]. Punica granatum L. (pomegranate) is a well-known fruit and is abundantly used throughout the world. It is widely used in traditional medicine for a variety of indications including anti-angiogenic, anti-cancer and antimicrobial $[107,108]$. Pomegranate contains a variety of phytochemicals (ellagitannins and gallotannins, catechins, procyanidins, flavonoids, anthocyanins and anthocyanidins) [109]. Its antimicrobial activity against $E$. coli has been reported by several researchers [110-112]. Traditional healers of the Limpopo province of South Africa use a variety of medicinal plants for treating diarrhea [113]. Mathabe et al. performed antibacterial experiments to scientifically validate the traditional use of plants against diarrhea/foodborne disease-causing bacteria, i.e; E. coli. Their findings confirmed the potential action of Gymnosporia senegalensis (Lam.) Loes., Indigofera daleoides Harv., Ozoroa insignis Delile, Punica granatum L., Spirostachys africana Sond. and Syzygium cordatum Hochst. ex Krauss in limiting E. coli infection [114]. Similarly, in Puerto Rico, traditional medicines are used as an alternative therapy for GIT infections. Tamarindus indica L., Phyllanthus acidus (L.), Punica granatum L., Citrus aurantifolia (Chrism.) Swingle, Citrus aurantium L. were active against $E$. coli [115].

\subsection{Staphylococcus aureus}

Staphylococcus aureus (S. aureus), a Gram-positive, coagulase producing facultative anaerobe is a major cause of foodborne diseases and hospitalization [104]. In addition to causing clinical infections, S. aureus also causes food poisoning (a foodborne disease). Individuals suffering from Staphylococcal food poisoning are presented with diarrhea, abdominal cramps, nausea and profuse vomiting usually between 1-8 h after food consumption [116]. This pathogen produces exoproteins that are heat stable and are known as Staphylococcal enterotoxins (SEs). These toxins act as virulence factors [117] and are mostly responsible for food poisoning and are grouped into five toxin groups designated classically as SEA to SEE. Other Staphylococcal enterotoxins (SEG to SER and SEU) have also been described recently [118-120]. Staphylococcal foodborne disease outbreak without harboring enterotoxins has also been reported [121]. Traditional medicine is widely practiced in South Africa for treating GIT problems. Bisi-Johnson et al. evaluated the anti-staphylococcal activity of plants used in traditional medicine for GIT related problems including diarrhea and vomiting which are indication of food poisoning. They found that the medicinal plants including Aloe arborescens Mill., Aloe striata Haw., Cyathula uncinulata (Schrad.) Schinz, Eucomis autumnalis (Mill.) Chitt., Eucomis comosa (Houtt.) Wehrh., Hypoxis latifolia Wight, Hermbstaedtia odorata (Burch. ex Moq.) T.Cooke, Scilla nervosa (Burch.) J.P.Jessop, Pelargonium sidoides DC., Psidium guajava L. and Hydnora africana Thunb. possess strong antibacterial potential towards $S$. aureus and validates the scientific evidence of the use of these plants for food poisoning caused by S. aureus [73]. The plant extracts of Aristolochia indica, Cuscuta pedicellata, Melilotus indicus and Tribulus terrestris fruit which are traditionally used in Pakistan for various ailments including diarrhea have anti-staphylococcal activity [122]. From Togo, anti-staphylococcal activity has been reported for Holarrhena floribunda (G.Don) T.Durand \& Schinz [123], from Cameroon, for Vismia rubescens Oliv., Vismia laurentii De Wild [124,125], from South Africa, Chrysophyllum albidum G. Don-Holl., Terminalia ivorensis A.Chev. [126,127], from Sudan, Combretum hartmannianum Schweinf., Combretum pentagonum M.A.Lawson, Anogeissus schimperi Hochst. ex Hutch. \& Dalziel and Terminalia arjuna (Roxb. ex DC.) Wight \& Arn. [128], from Egypt, clove (Syzygium aromaticum), cress (Lepidium sativum L.), lemongrass 
(Cymbopogon citratus (DC.) Stapf.), Oregano (Origanum vulgare L.), rosemary (Rosmarinus officinalis L.), sage (Salvia officinalis L.) [129], from Algeria, Stachys guyoniana Noë ex Batt. and Mentha aquatic L., Centaurea diluta Ait. subsp. algeriensis, Ferula vesceritensis Coss. \& Durieu ex Trab., Genista saharae Coss. \& Durieu and Zilla macroptera Coss. [130-132] and Clerodendrum myricoides (Hochst.) R. Br. ex Vatke from Kenya, [133].

Juglone is a natural compound occurring in plants such as black walnut (Juglans nigra L.). This compound has antibacterial property and inhibits $S$. aureus by binding to DNA and disrupts cell wall synthesis, thus stressing the bacterial cells to increasing peroxidative environment [134]. Tetrandrine is an alkaloid isolated from the radix of Stephania tetrandra S. Moore. It inhibits S. aureus by binding to the peptidoglycan [135]. Fraxinus rhynchophylla Hance and its active constituent fraxetin is antibacterial to S. aureus via inhibition of essential proteins synthesis. It also decreases the activity of topoisomerase I and topoisomerase II [136]. Several researchers have reported active compounds from medicinal plants that are active against staphylococcal bacteria [137-139]. Essential oils are also utilized against S. aureus and studies have shown potential benefits of essential oils derived from Petroselinum crispum (Mill.) Fuss, Cuminum cyminum L, white mustard (Sinapis alba L.), Chamaecyparis obtusa (Siebold \& Zucc.) Endl. [140-143].

\subsection{Shigella}

Shigella is a genus of Gram-negative bacteria. It has four species, S. flexneri, S. sonnei, S. dysenteriae and S. boydii. These are rod-shaped, non-motile, non-spore forming and facultative anaerobic bacteria [144]. They cause diseases commonly known as shigellosis, characterized by profuse watery diarrhea, fever, abdominal cramps and also bloody dysentery. Ingestion of as low as 100 numbers of these bacteria can cause foodborne disease. These bacteria attack the epithelial cells of the colon of primates only. The resultant inflammation causes high intestinal motility and diarrhea which even leads to dysentery [145]. The virulence of Shiga toxin is like that of verotoxin of E. coli, which halts protein synthesis in the host cells $[104,146]$. In Iran, pomegranate (Punica granatum) is commonly used to treat diarrhea. Mahboubi et al. reported that the the extracts of pomegranate were active against Shigella [147]. Another study has reported the anti-Shigella activity of five plants, e.g., Thymus vulgaris L., Thymus carmanicus Jalas, Zataria multiflora Boiss., Ziziphora clinopodioides Lam. and Ziziphora tenuior L. Among these Thymus caramanicus and Zataria multiflora were found comparatively more active having MIC values of 0.78 and $1.56 \mathrm{mg} / \mathrm{mL}$, respectively [148]. In a study by Vuuren et al. 23 traditionally used plants for various ailments including diarrhea, were subjected to antibacterial activity against Shigella bateria. Although, all the plants had antibacterial property, Acacia burkei Benth. (MIC $0.25 \mathrm{mg} / \mathrm{mL}$ ), Acanthospermum glabratum (DC.) Wild (0.44 mg/mL), Brachylaena transvaalensis Hutch. ex E.Phillips \& Schweick. (0.5 mg/mL), Catharanthus roseus (L.) G.Don $(0.41 \mathrm{mg} / \mathrm{mL})$, Chenopodium ambrosioides L. (0.5 mg/mL), Cissampelos hirta Klotzsch $(0.38 \mathrm{mg} / \mathrm{mL})$, Gymnosporia senegalensis (Lam.) Loes. $(0.63 \mathrm{mg} / \mathrm{mL})$, Lippia javanica $(0.5 \mathrm{mg} / \mathrm{mL})$, Mangifera indica L. $(0.25 \mathrm{mg} / \mathrm{mL})$, Melia azedarach L. $(0.57 \mathrm{mg} / \mathrm{mL})$, Psidium guajava L. $(0.33 \mathrm{mg} / \mathrm{mL})$, Sarcostemma viminale (L.) R.Br. $(0.5 \mathrm{mg} / \mathrm{mL})$, Schotia brachypetala Sond. $(0.58 \mathrm{mg} / \mathrm{mL})$, Sclerocarya birrea (A.Rich.) Hochst. $(0.34 \mathrm{mg} / \mathrm{mL})$, Syzygium cordatum Hochst. ex Krauss $(0.43 \mathrm{mg} / \mathrm{mL})$ and Terminalia sericea Burch. ex DC. $(0.04 \mathrm{mg} / \mathrm{mL})$ were particularly potent [149]. Essential oils are also utilized for foodborne infections caused by Shigella $[150,151]$.

\subsection{Listeria monocytogenes}

Listeria monocytogenes (L. monocytogenes), a Gram-positive, non-spore-forming, facultative anaerobe widely affecting food, meat, poultry and seafood [152]. This pathogen grows between 0.4 and $50{ }^{\circ} \mathrm{C}$ [104]. The virulence factors of L. monocytogenes include the production of beta hemolysin, catalase and superoxide dismutase. It has been implicated in foodborne outbreaks [153]. This microbe can survive refrigeration, high salt content and low $\mathrm{pH}$ [154]. These properties enable L. monocytogenes to contaminate food even after food postprocessing [155]; L. monocytogenes being a foodborne pathogen is 
challenged with extracts and compounds derived from medicinal plants. In a study by Yoon et al. in South Korea, 69 herbal extracts were tested for inhibition of L. monocytogenes. Psoraleae Semen and Sophorae Radix extracts were found potent in their study [156]. Attachment of L. monocytogenes to the human intestinal epithelium and its subsequent invasion results in listeriosis. Motility, lecithinase and hemolysin production are the major virulence factors of this pathogen. The virulence factors, i.e., motility, lecithinase and hemolysin production were also decreased. Furthermore, the expression of the virulence genes was downregulated by cinnamaldehyde, carvacrol and thymol more than 3 -folds $[157,158]$. The essential oils are reported to possess antilisterial activity. Essential oils of Zataria multiflora Boiss. from Turkey [159], Carum copticum (L.) Benth. \& Hook.f. ex C.B.Clarke from Iran [160], Thymus capitatus (L.) Hoffmanns. \& Link from Tunisia [161], Cymbopogon citratus D.C. Stapf. from Brazil [162], Eryngium foetidum L. from Italy [163] have been reported to have the potential of inhibiting L. monocytogenes.

\subsection{Clostridium spp.}

Clostridium botulinum (C. botulinum) is a Gram-positive, rod-shaped, motile, obligate anaerobe [164]. It is a spore-forming bacterium and produces a neurotoxin known as botulinum [165]. It causes a foodborne disease known as foodborne botulism. This happens after ingestion of the preformed toxin produced by C. botulinum. The major virulence factor is toxin production [166]. Seven types of toxins have been identified. These are named as A-G. Among these, A, B and E toxin types are associated with foodborne illness. The symptoms of foodborne botulinum are blurred vision, dry mouth, nausea, vomiting, abdominal cramps and difficulty in swallowing $[167,168]$. Toosendanin, a natural compound, prevents botulinum in animals [169].

C. perfringens, a Gram-positive, spore-forming bacteria has a widespread anaerobic environmental distribution including soil, foodstuff and is part of human flora [170]. Extracts from traditionally important medicinal plants including Psidium guajava L., Haematoxylum brasiletto H.Karst. and Euphorbia prostrata Aiton were found highly effective against $C$. perfringens type A [171]. Likewise, essential oils from Satureja montana L. tested against $C$. perfringens type A a concentration of $1.56 \%$, showed inhibitory activity causing structural damage and cell lysis. Moreover, a synergistic effect between $\mathrm{NaNO}_{2}$ and Satureja montana EOs was observed and the findings suggest the potential combined use of savory essential oil and minimal amounts of the synthetic additive, $\mathrm{NaNO}_{2}$ to control C. perfringens [172]. The natural product, berberine demonstrated efficacy towards the $C$. perfringens disease based on significantly decreased mortality and lesion scores at $1.0 \mathrm{~mL} / \mathrm{L}$, in vitro [173]. Extracts from several plants Pueraria thunbergiana (Siebold \& Zucc.) Benth., Astragalus membranaceus (Fisch.) Bunge, Eucommia ulmoides Oliv., Coptis japonica (Thunb.) Makino, Akebia quinata (Houtt.) Decne. and Rhus chinensis Mill. exhibited considerable activity against $C$. perfringens [174].

\subsection{Bacillus cereus}

B. cereus, a Gram-positive spore-forming bacterium, is frequently implicated in foodborne infections. Among the pathogenic aspects of the bacterium is the production of tissue-damaging exo-enzymes. The bacterium secretes toxins including hemolysins, phospholipases, emesis-inducing toxins and proteases [175]. In the in vitro antibacterial assay against B. cereus, the extract of Dryopteris erythrosora (D.C. Eaton) Kuntze exhibited an MIC of $0.0156 \mathrm{mg} / \mathrm{mL}$, followed by Siegesbeckia glabrescens (SG) Makino leaf $(0.0313 \mathrm{mg} / \mathrm{mL})$, Morus alba L. bark $(0.0313 \mathrm{mg} / \mathrm{mL})$, Carex pumila Thunb. root $(0.0625 \mathrm{mg} / \mathrm{mL})$ and Citrus paradisi Macfad. seed $(0.0625 \mathrm{mg} / \mathrm{mL})$ extracts. The combined inhibitory effects of extracts against B. cereus were also determined. A combination of D. erythrosora and C. pumila extracts showed a partial synergistic inhibition, with a fractional inhibitory concentration index of 0.75 . The single and combined inhibitory activities of selected plant extracts against $B$. cereus in reconstituted infant rice cereal were also investigated and showed the MICs of S. glabrescens, M. alba, D. erythrosora and C. pumila extracts against B. cereus as 1.0, 2.0, 2.0 and $8.0 \mathrm{mg} / \mathrm{mL}$, respectively [176]. The plant extracts of Rhus coriaria L. and Hipiscus sabdariffa L. were investigated against six presumptive Bacillus 
cereus isolates that were isolated from 49 samples of food, soil, manure and eggshells in Amman, Jordan. It was observed that the inhibition of the growth of bacteria was proportional to the increase in extract concentrations. Complete inhibition of the growth was demonstrated at the highest concentrations. The authors concluded that Rhus coriaria and Hibiscus sabdariffa have the potential to be used as food preservatives against wider spectra of spoilage microorganisms in food [177].

\subsection{Vibrio cholerae}

$V$. cholerae, a Gram-negative curved rod from family Vibrionaceae has two major virulence factors including cholera toxin, causing profuse rice-watery diarrhea and toxin-coregulated pilus that is mediated in intestinal colonization [178]. Cholera caused by toxigenic $V$. cholerae is a major public health problem particularly in less developed regions of the world with poor sanitation facilities [179]. The extracts of Ocimum basilicum L., Opuntia ficus-indica (L.) Mill., Acacia farnesiana (L.) Willd. and Artemisia ludoviciana Nutt. were found active against $V$. cholera, with MBCs values ranging from 0.5-3.0-mg/mL [180]. Recently, solvent-based extracts from red chili, sweet fennel and white pepper were reported to inhibit cholera toxin production. Further, capsaicin the active ingredient of chili prevented the synthesis of cholera toxin in different strains of $V$. cholerae. Capsaicin declined the expression of virulent genes ( $c t x A, t c p A$ and toxT) yet increased the expression of $h n s$ gene that transcribes a global prokaryotic gene regulator (H-NS) [181]. Solvents based extracts from 32 Mexician plants were evaluated for their inhibitory effects against $V$. cholera strains (O1, O139). Among these, Acacia farnesiana and Artemisia ludoviciana ethanolic extracts were more effective with minimum Bactericidal Concentrations of 4.0-7.0 and 4.0-6.0-mg/mL respectively [182]. In another study, the extracts of Terminalia chebula Retz. and Syzygium cumini (L.) Skeels exhibited considerable activity against $V$. cholerae, Aeromonas hydrophila and Bacillus subtilis, with MBCs $(0.25-4 \mathrm{mg} / \mathrm{mL})$. These results favor the use of ethnopharmacological important plants in the management of diarrhea, especially those associated with cholera [183].

\section{Plant Extracts and Phytochemicals against Viruses Causing Foodborne Diseases}

\subsection{Norovirus}

Norovirus is single-stranded, positive-sense RNA and non-enveloped virus which is also known as winter vomiting bug [184]. It is a major cause of acute gastroenteritis affecting people of all ages. The transmission of the virus occurs via contaminated food. After entry into the body, the virus replicates in the intestines. It takes one to two days for symptoms to appear. The major symptom reported is gastroenteritis [185]. Other symptoms include watery diarrhea, abdominal cramps, nausea and vomiting. The infection is self-limiting, and recovery occurs within two to three days. There is no specific treatment for norovirus infection. Supportive therapy includes maintaining fluid and electrolyte balance [186]. A combination of juice and polyphenols from pomegranate is effective for eradicating norovirus infection [187]. Chinese galls and pomegranate significantly reduces the attachment of norovirus P protein to their receptors (human histo-blood group antigens) which is an important step for this pathogen virulence. Along with other phytochemicals, tannic acid is responsible for this blocking action [188]. Similarly, grape (Vitis vinifera L.) seed extract is used in GIT diseases and has been proved to have potential anti-norovirus activity [189]. Allspice oil and lemongrass oil can reduce viral infection by degrading the capsid of the virus [190]. Curcumin, a natural compound from Curcuma longa L. and juice of mulberry (Morus alba L.) were tested for anti-noroviral activity and were found to have good inhibitory activity on norovirus.

\subsection{Astrovirus}

Astroviruses are non-enveloped, positive-sense single-stranded RNA viruses causing GIT disorders particularly pediatric diarrhea. The astrovirus capsid acts as enterotoxin and thus disrupts gut epithelial barrier [191]; Achyrocline bogotensis (Kunth) DC. extracts were evaluated for their 
antirotavirus (RRV) and anti-astrovirus (Yuc8) activities. The nontoxic concentrations displayed considerable antiviral potentials against both viruses. The activity can be attributed to the presence of steroids, sterols, terpenes, phenols, flavonoids and sesquiterpene lactones [192]. Spirulina platensis ethanolic extract was tested and revealed a considerable decline in vitro for infectious units of various types of viruses including adenovirus (type 7), astrovirus (type 1), Coxsackievirus B4, rotavirus (Wa strain) and adenovirus (type 40) [193]. Northern Nigerian plants have been investigated against poliovirus, astrovirus, herpes simplex viruses and parvovirus. The obtained results showed that the test samples showed considerable activity against viruses at 100-400 mg/100 mL dose [194].

\subsection{Hepatitis-A Virus}

The hepatitis A virus (HAV), a picornavirus is a widespread cause of hepatitis and is transmitted via oral intake of contaminated food, water and blood transfusion [195]. Medicinal plants including Alnus japonica (Thunb.) Steud. have revealed significant virucidal activity against HAV and at a concentration of $50-\mu \mathrm{g} / \mathrm{mL}$ has reduced HAV titer by $3.43 \pm 0.24$ logs. Similarly, Artemisia annua L., Allium sativum L., Allium fistulosum L. and Agrimonia pilosa Ledeb. extracts exhibited $2.33 \pm 0.43$, $2.10 \pm 0.41,2.07 \pm 0.60$ and $2.03 \pm 0.26-\log$ reductions, respectively [196]. It has been observed that green tea extract has a strong anti-HAV activity with a direct effect on the viral particles. Supplementing tap water with the extract with continuous shaking every $15 \mathrm{~min}$ for $1 \mathrm{~h}$ caused a significant reduction in the percentage of HAV plaque counts. There is a strong recommendation of supplementing water with a small concentration of green tea extract that does not cause an observed change in its color and taste for $1 \mathrm{~h}$ with persistent shaking before usage in endemic areas for HAV infections [197].

\subsection{Rotavirus}

Rotavirus infections represent the leading cause of dehydrating gastroenteritis among children less than 5 years of age. Despite the worldwide vaccinations against rotavirus, it is still a major cause of fatality ( $>200,000$ deaths annually) especially in low-income countries [198]. These viruses usually infect enterocytes, thus induce diarrhea via the decline in the absorptive capacity of enterocytes, increase intestinal secretion stimulated by viral non-structural protein 4 and activation of the enteric nervous system [199]. It has been observed that supplementation Nelumbo nucifera Gaertn., Aspalathus linearis (Burm.f.) R.Dahlgren, Urtica dioica L., Glycyrrhiza glabra L. and Olea europaea L. extracts are effective in the managment of rotavirus induced diarrhea [200,201]. Moreover, aqueous extracts from Nelumbo nucifera, Urtica dioica, Aspalathus linearis, Glycyrrhiza glabra and Olea europaea leaves were reported to exhibit substantial antiviral potentials with $\mathrm{IC}_{50}$ of $<300 \mu \mathrm{g} / \mathrm{mL}$. Likewise, $18 \beta$-glycyrrhetinic acid and luteolin isolated from G. glabra and A. linearis exhibited $\mathrm{IC}_{50}$ of $46 \mu \mathrm{m}$ and $116 \mu \mathrm{m}$, respectively [201]. Rubia cordifolia L. extracts, isolated compounds including xanthopurpurin and vanillic acid were quite effective against rotavirus and inhibited its multiplication by augmenting virus-mediated apoptosis in MA-104 cells [202]. The antirotavirus activity of Bauhinia variegata $\mathrm{L}$. was examined, which showed antiviral activity against rotavirus in vitro with therapeutic index ranged from 0.2 to 23 and a reduction in virus titers ranged from $0.25 \log _{10}$ to $4.75 \log _{10}$. These results demonstrated that $B$. variegata has a potential for the pharmacotherapeutic management of rotavirus induced gastroenteritis [203]. The antiviral activity of different extracts from Calliandra haematocephala Hassk. leaves against rotavirus $(\mathrm{RV})$ infection was evaluated both in vitro and in vivo. C. hematocephala at non-cytotoxic concentrations exhibited antirotavirus activities at a different magnitude of potency with therapeutic index ranging from 1.3 to 32 and a reduction in virus titer ranging from $0.25 \log _{10}$ to $5.75 \log _{10}$. In the in vivo study, oral administration of the methanol extract at $50 \mathrm{mg}$ and $100 \mathrm{mg} / \mathrm{kg} /$ day significantly reduced mortality, virus titers, duration and severity of diarrhea, as well as alleviation of lesion in the small intestine in rotavirus infected mice [204]. The leaf of Japanese big-leaf magnolia (Magnolia obovate Thunb.) has long been used as a natural packaging material for traditional foods in Japan. The extract significantly inhibited cytopathic effects and mRNA expression of rotaviral proteins in SA11-infected MA104 cells 
and thus can be used as a medicine or food additive to prevent and ameliorate rotavirus-induced diarrhea in individuals that may have difficulty in benefitting from the rotavirus vaccines [205].

\section{Plant Extracts and Phytochemicals against Parasites Causing Foodborne Diseases}

\subsection{Giardia lambia}

Giardiasis is a human parasitic infection most commonly transmitted through the ingestion of infected food and is associated with significant morbidity [206]. The most common cause of giardiasis is the protozoan, Giardia lamblia commonly called G. intestinalis and G. duodenalis. Several treatment strategies are devised for its eradication which includes nutritional intervention, ingestion of probiotics and phytotherapeutic agents [207]. Several natural products including Allium sativum, berberine and flavonoid-rich herbs, Piper longum L., Butea monosperma (Lam.) Taub. and various isolated compounds have been found effective in the eradication of giardiasis [208,209].

Natural products based therapeutics play a significant role in the treatment and management of giardiasis, mediated through eradication of parasite and thus relieving the unwanted symptoms of infection. Several herbs are extensively reported for their effectiveness in Giardia infections; Allium sativum is a well-known household remedy against numerous human diseases including microbial and parasitic infections [210]. In a study, Harris et al. reported the anti-giardial potentials of crude A. sativum and its isolated compounds; A. sativum crude extract exhibited $\mathrm{IC}_{50}$ of $0.3-\mathrm{mg} / \mathrm{mL}$ against Giardia intestinalis, whereas, the isolated compounds allyl mercaptan, diallyl disulfide, diallyl sulfide, allyl alcohol and dimethyl disulfide showed $\mathrm{IC}_{50}$ values of $0.037,0.1,1.3,0.007$ and $0.2 \mathrm{mg} / \mathrm{mL}$, respectively [33].

Furthermore, the incubation of Giardia trophozoites in the presence of whole A. sativa exhibited considerable decline in the parasite motility, flagellar movement and ultimate swelling of the trophozoite. The mechanisms underlying these events involve the loss of osmoregulation of parasite and loss of transmembrane electrochemical gradient. Microscopic studies revealed morphologic changes in the ventral disc of the parasite which can be responsible for its inability to attached to its host cell [33]. In another clinical study, Soffar and Mokhtar administered fresh A. sativum distilled water extract $(5 \mathrm{~mL})$ or $0.6 \mathrm{mg}$ commercially available capsules to 26 children infected with $\mathrm{G}$. lamblia for three days and observed its beneficial effects against giardiasis [211]. The symptoms of giardiasis were effectively subsided in all the groups of children with thirty-six hours of therapy and the stool examination revealed complete eradication of parasite [211]. Allicin isolated from A. sativum is reported to mediate its action against the parasite via inhibition of giardia's cysteine proteases and inhibition of products responsible for unwanted symptoms of giardiasis [212,213]. Moreover, A. sativa also increases the mucosal nitric oxide (NO) production via stimulation of nitric oxide synthase, which subsequently increases the liberation of $\mathrm{NO}$ from enterocytes and exhibits direct giardicidal effects [33].

Piper longum L. is a well-known folk medicine for the treatment of gastrointestinal disorders and helminthesis [214]. In a study, Tripathi et al. investigated the giardicidal actions of crude extracts of P. longum. Treatment with crude ethanolic extract $(125 \mu \mathrm{g} / \mathrm{mL})$ and aqueous extracts $(250 \mu \mathrm{g} / \mathrm{mL})$ showed 100\% lethality against Giardia lamblia. In an animal model of giardiasis, P. longum crude ethanolic extract, aqueous extract and fruit powder at doses of 250, 450 and $900 \mathrm{mg} / \mathrm{kg}$, respectively significantly $(75 \%)$ diminished the live trophozoites count in the intestinal mouse aspirates after five days of therapy [215]. The two important gastroprotective herbs including Piper longum and Butea monosperma have been combined in a traditional herbal formulation called Pippali rasayana (PR). This formulation is very famous in folk medicine for the treatment of helminthesis and chronic dysentery. In a study, Agarwal et al. reported the anti-giardial effects of PR formulation in an animal model. The in vivo study revealed that PR administration in doses of 225,450 and $900 \mathrm{mg} / \mathrm{kg}$ exhibited $62 \%, 79 \%$ and $98 \%$ parasitic clearance, respectively. Moreover, PR significantly augmented the macrophage phagocytic activity and macrophage migration index at all the tested doses. As the PR formulation is inactive against the parasite in vitro, so it was proposed that the formulation may 
mediate its anti-giardial activity through boosting of host immune system and thereby increasing clearance mechanisms [216]. To further explore the clinical significance of PR formulation, Agarwal et al. extended the study and included fifty human subjects with all signs and symptoms of giardiasis including cysts and Giardia trophozoites in the stool samples. The subjects were divided into two groups; the treated group was maintained on PR (1 g T.D.S) for fifteen days, whereas the second group served as a placebo control. After the completion of therapy, stool samples were analyzed for G. lamblia, frequency of diarrhea and mucous content of the stool. In the treated group, $92 \%$ inhibition of Giardia and a significant decline in diarrhea and mucous were observed. A boost in the cell-mediated immune system indicated by a decline in leukocyte migration was also observed [217].

In a study, Miyares et al. evaluated the giardicidal potential of propolis in 136 subjects with well-known symptoms of giardiasis. In the five days' trials, propolis was administered in $20,30 \%$ solutions (adults) and 10\% solution (children) and duodenal aspirates were evaluated for giardicidal activity. Results of the study revealed $60 \%$ giardicidal activity for $30 \%$ solution and $40 \%$ giardicidal activity for $20 \%$ solution in adults whereas, $52 \%$ giardicidal activity was observed in children after administration of $10 \%$ solution. The standard drug, tinidazole exhibited a $40 \%$ efficacy [218]. Several studies have confirmed the efficacy of berberine and berberine rich plants including Coptis chinensis Franch., Berberis vulgaris L., Berberis aquifolium Pursh, Berberis aristata DC. and Hydrastis canadensis L. in the management of gastrointestinal disorders like parasitic infestation and diarrhea $[219,220]$. Berberine is highly effective against Giardia trophozoites and mediates its beneficial effects via morphologic changes in the trophozoites including changes in the shape of vacuoles, trophozoites swelling and deposition of glycogen deposits [221]. Berberine hydrochloride at a dose of $5 \mathrm{mg} / \mathrm{kg}$ showed a $68 \%$ decline in the stool-Giardia content and a significant decline in giardiasis symptoms in a clinical study [222]. In a clinical trial, berberine administered in doses of 5, $10 \mathrm{mg} / \mathrm{kg}$ for 5-10 days showed a $47 \%, 55 \%, 68 \%$ and $90 \%$ decline in the Giardia content in all the treated groups of children. The standard drugs, furazolidone and metronidazole exhibited a $92 \%$ and $95 \%$ efficiency against Giardia [223]. In vitro studies have revealed high efficacy of crude extracts from these plants in comparison to pure berberine, which can be attributed to the synergistic interactions of berberine with other isoquinoline alkaloids present in these plants [224]. Natural flavonoids including epicatechin, quercetin, epigallocatechin, apigenin and kempferol, which are abundant in several natural products like Quercus robur L., Hamamelis virginiana L. and Croton lechleri Müll.Arg. are extensively reported for giardicidal potentials [225-227]. In a study, flavonoids and tannins rich plants including Origanum vulgare L., Psidium guajava L., Mangifera indica L. and Plantago major L. showed high anti-giardial activity in comparison to the standard drug, tinidazole [228]. Barbosa E et al. reported the antigiardial activity of flavonoids isolated from Geranium mexicanum Kunth, Helianthemum glomeratum (Lag.) Lag. ex Dunal, Cuphea pinetorum Benth. and Rubus coriifolius Liebm. Among the isolated compounds, kempferol, tiliroside and epicatechin exhibited $\mathrm{IC}_{50}$ values of $2.057,1.429$ and $0.072 \mu \mathrm{mol} / \mathrm{kg}$, respectively against G. lambia [229].

\subsection{Entamoeba histolytica}

Amoebiasis is a ubiquitous gastrointestinal disorder most prevalent in less developed countries with poor sanitation and socioeconomic status, affecting about $12 \%$ of global population [230]. It is known to be the third leading cause of mortality [231-233]. The causative agent of amoebiasis is Entamoeba histolytica, which is associated with typical symptoms of amoebic dysentery, abdominal cramps, bloating or tenderness and stomachache [234,235]. Among the currently available chemotherapeutics, metronidazole is an effective amoebicide, but is associated with unwanted side-effects like carcinogenesis, mutagenesis, nausea and vomiting [236,237]. The stratagem of utilizing natural drugs in antiamoebic therapy traces back to the pre-historic era. For instance, emetine isolated from Cephaelis ipecacuanha (Brot.) A.Rich. is used as a front line anti-amoebic drug [238]. Currently, a large population is dependent on traditional therapeutics for the management of various diseases $[18,25,239]$. Medicinal plant and herbal drugs represent an indispensable part of the traditional 
medicine practiced in many countries owing to low costs, frequent availability, biosafety and ancestral knowledge [240-242]. Hence, in search of more effective drugs, traditionally used natural products are of great importance. Several natural products and isolated compounds have been scientifically validated for effective eradication of Entamoeba histolytica, for potential drug development. For instance, bruceantin, a potent amoebicide from Brucea antidysenterica J.F.Mill. exhibited $\mathrm{IC}_{50}$ of $0.018 \mu \mathrm{g} / \mathrm{mL}$ [243], parthenin from Parthenium hysterophorus L. [244], extracts and isolated compounds from Brucea javanica (L.) Merr. fruits and Simarouba amara Aubl. [245] and alkaloids from Alstonia angustifolia Wall. ex A.DC. roots [246] were extensively studied against E. histolytica. Cimanga et al. investigated the effect of Morinda morindoides (Baker) Milne-Redh. leaves extracts and isolated compounds against E. histolytica [247]. The crude methanolic extract and aqueous decoction showed significant anti-amoebic action with $\mathrm{IC}_{50}$ values of 1.7 and $3.1 \mu \mathrm{g} / \mathrm{mL}$, respectively. Among the isolated compounds, kempferol, apigenin, luteolin, apigenin-7-O-glucoside and luteolin-7-O-glucoside exhibited $\mathrm{IC}_{50}$ values of 10.3, $12.7,17.8,22.3$ and $37.4 \mu \mathrm{g} / \mathrm{mL}$, respectively against $E$. histolytica.

Tona et al. evaluated forty-five Congolese plant extracts used in traditional medicine against $E$. histolytica. Among the tested samples, Mangifera indica L., Rauwolfia obscura K.Schm., Carica papaya L., Euphorbia hirta L., Hymenocardia acida Tull., Jatropha curcas L., Maprounea africana Mull. Arg., Paropsia brazzeana Baill., Psidium guajava L., Cryptolepis sanguinolenta (Lindl.) Schltr. and Quassia africana (Baill.) Baill. were highly active with $\mathrm{IC}_{50}$ values of $7.81,31.5,7.81,31.25,31.25,31.25,31.25,7.81,7.81,7.81$ and $31.5 \mu \mathrm{g} / \mathrm{mL}$, respectively [248]. In another study, Sohni et al. investigated the antiamoebic potentials of an herbal formulation containing Zingiber officinale, Berberis aristata, Boerhavia diffusa L., Tinospora cordifolia (Willd.) Miers and Terminalia chebula extracts. Among these plant extracts, Berberis aristata and Tinospora cordifolia showed $\mathrm{IC}_{50}$ values of 100 and $1000 \mu \mathrm{g} / \mathrm{mL}$, respectively. All these plants in a combined formulation exhibited an $\mathrm{IC}_{50}$ of $1000 \mu \mathrm{g} / \mathrm{mL}$. The herbal formulation was also tested against some enzymes of E. histolytica including DNase, RNase, aldolase, alkaline, acid phosphatases and $\alpha$-amylase that are known to play a significant role in the virulence and invasiveness of the parasite. Results confirmed various degrees of inhibition of these enzymes [249]. Owing to the traditional use of Salvia polystachya Cav. for the treatment of dysentery in the Mexican traditional medicine, Calzada et al. investigated various isolated compounds from Salvia polystachya against E. histolytica and G. lamblia trophozoites. Among the tested compounds, Linearolactone was most active showing $\mathrm{IC}_{50}$ value of 22.9 and $28.2 \mathrm{mM}$ against E. histolytica and G. lamblia, respectively. Whereas, polystachynes A, B and $\mathrm{D}$, exhibited modest antiprotozoal potentials with $\mathrm{IC}_{50}$ values ranging from $117.0-160.6 \mathrm{mM}$ against E. histolytica and 107.5-134.7 mM against G. lamblia [250].

In the search for new antiprotozoal drugs from natural products, Calzada et al. studied the inhibitory effects of twenty-six traditional Mexican drugs against E. histolytica and G. lamblia. Among the tested samples, Chiranthodendron pentadactylon Larreat., Annona cherimola Mill., Punica granatum, Dichondra argentea Humb. \& Bonpl. ex Willd., Chenopodium ambrosioides L. and Chrysactinia mexicana A.Gray were most active showing $\mathrm{IC}_{50}$ values of $2.5,14.8,29.5,38.3,45.2,45.3 \mu \mathrm{g} / \mathrm{mL}$, respectively against E. histolytica. Whereas, Dorstenia contrajerva L., Senna villosa (Mill.) H.S. Irwin \& Barneby, Ruta chalepensis L., Cocos nucifera L. and Chiranthodendron pentadactylon Larreat. exhibited $\mathrm{IC}_{50}$ values of $23.3,32.1,37.8,44.1,44.2 \mu \mathrm{g} / \mathrm{mL}$, respectively against G. lamblia [251]. In another study, the same group investigated the antiprotozoal efficiency of crude extracts and isolated compounds from the roots of Geranium mexicanum against E. histolytica and G. lamblia. Among the crude samples, dichloromethane-methanol, ethyl acetate, fraction 13 (from ethyl acetate) and aqueous fractions showed $\mathrm{IC}_{50}$ values of 79.2, 66.7, 51.5 and $221.6 \mu \mathrm{g} / \mathrm{mL}$, respectively against $E$. histolytica and 100.4, 63.7, 59.7 and $215.9 \mu \mathrm{g} / \mathrm{mL}$, respectively against G. lamblia. Among the isolated compounds, epicatechin, catechin, $\beta$-sitosterol 3-O- $\beta$-D-glucopyranoside and tyramine revealed $\mathrm{IC}_{50}$ values of $1.9,65.6,82.2$ and $54.2 \mu \mathrm{g} / \mathrm{mL}$, respectively against $E$. histolytica and $1.6,33.9,61.5$ and $68.9 \mu \mathrm{g} / \mathrm{mL}$, respectively against $G$. lamblia [252]. The antiprotozoal potential of another traditional plant, Rubus coriifolius and its isolated compounds were investigated by Alanís et al. against E. histolytica and G. lambia. In the crude fractions, dichloromethane-methanol was most active with $\mathrm{IC}_{50}$ values of 11.6 and $55.6 \mu \mathrm{g} / \mathrm{mL}$, respectively 
against E. histolytica and G. lamblia. Whereas, the isolated compounds including epicatechin, catechin, nigaichigoside, $\beta$-sitosterol-3-O- $\beta$-D-glucopyranoside, hyperin, gallic acid and ellagic acid exhibited $\mathrm{IC}_{50}$ value of $1.9,65.5,111.9,82.16,143.6,220$ and $56.5 \mu \mathrm{g} / \mathrm{mL}$, respectively against $E$. histolytica and 1.6, 34.0, 123.6, 61.5, 49.2, 70.3 and $24.9 \mu \mathrm{g} / \mathrm{mL}$, respectively against $\mathrm{G}$. lamblia [253].

\subsection{Toxoplasma gondii}

Toxoplasmosis is a parasitic infection caused by Toxoplasma gondii and transmitted from infected pregnant women and contaminated food and is a major cause of foodborne hospitalization and death [254]. Meat from various sources including pork, cattle, wild game meat, poultry meat, lamb if not properly cooked and vegetables contaminated with oocysts, infected water and feces can cause transmission of toxoplama infection [255]. Proper cleansing, cooking of meat and washing of fruits and vegetables can significantly reduce the risk of toxoplasmosis. Immunocompromised and organ transplant individuals are at more risk to develop this infection. Several toxoplasmosis outbreaks in Korea are reported to be linked with the use of uncooked pork [256]. Toxoplasmosis is reported as a major cause of neurologic infections in HIV infected individuals [257]. Toxoplasmosis is reported as the second major cause of foodborne infections and the fourth major cause of hospitalization and deaths in the United States [4]. In Greece, toxoplasmosis has been reported among the top five contributors of foodborne infections, leading to major disabilities and deaths [258].

Several studies regarding the efficacy of natural products against toxoplasmosis have been reported. In a study, Youn et al. reported the antiparasitic potentials of traditionally used plant extracts against Toxoplasma gondii and Neospora caninum [259]. Solvent extracts of Sophora flavescens Aiton, Torilis japonica (Houtt.) DC., Ulmus macrocarpa Hance, Sinomenium acutum (Thunb.) Rehder \& E.H.Wilson and Pulsatilla koreana (Yabe ex Nakai) Nakai ex T. Mori collected from South Korea were tested. Among the tested herbs, T. japonica exhibited significant inhibitory potential against T. gondii by inhibiting parasite proliferation from $54 \%$ to $99 \%$ at $19.5-156 \mathrm{ng} / \mathrm{mL}$; S. flavescens extracts restrain $T$. gondii growth by $27.2-98.7 \%$ at a concentration ranging from $39-\mathrm{ng} / \mathrm{mL}$ to $156 \mathrm{ng} / \mathrm{mL}$. Extracts from other plants including Pulsatilla koreana, U. macrocarpa and S. acutum showed moderate antiparasitic activity against $T$. gondii. Wright et al. tested the effectiveness of isolated compounds from Simarouba amara and Brucea javanica fruits against Toxoplasma gondii, E. histolytica and Giardia intestinalis. Among the tested compounds, ailanthinone, bruceantin, bruceine $\mathrm{B}$, bruceine $\mathrm{C}$, bruceine $\mathrm{D}$, brusatol, glaucarubinone and quassin exhibited $\mathrm{IC}_{50}$ values of $0.0251,0.0115,0.75,0.842,7.56,0.179,0.374$ and $111 \mu \mathrm{M}$, respectively [260].

In a study, Choi et al. tested methanolic extracts from fifteen traditional herbs against $T$. gondii. Among the tested samples, Sophora flavescens, Zingiber officinale, Meliae Cortex, Acorus gramineus Aiton, Dryopteris crassirhizoma Nakai and Glycyrrhiza glabra were potent and exhibited $\mathrm{EC}_{50}$ values of 0.20 , $0.18,0.77,0.11,0.15$ and $0.13 \mathrm{mg} / \mathrm{mL}$, respectively against Toxoplasma gondii [261].

\subsection{Cryptosporidium}

Cryptosporidium spp. belongs to the family, Cryptosporidiidae. The most common species that cause human infection are the Cryptosporidium parvum and Cryptosporidium hominis. They can be transmitted from animals, human-to-human, water, food, and tend to cause waterborne outbreaks. The clinical manifestation in immunocompetent patients is self-limiting when compared to immunocompromised individuals where it causes chronic diarrhea not responding to treatment [262]. Cryptosporidium spp. are well recognized as causes of diarrheal disease and is increasingly identified as an important cause of morbidity and mortality worldwide [263]. The ethanolic extract from olive (Olea europaea) pomace, after oil pressing and phenol recovery, reproducibly inhibited Cryptosporidium paroum development $\left(\mathrm{MIC}=250-500 \mu \mathrm{g} / \mathrm{mL}, \mathrm{IC}_{50}=361(279-438) \mu \mathrm{g} / \mathrm{mL}, \mathrm{IC}_{90}=467(398-615) \mu \mathrm{g} / \mathrm{mL}\right)$ [264]. In an in vivo study, the extract of Curcuma longa L. had the highest effect on Cryptosporidium oocysts shedding. The inhibitory effect was observed at a rate of $100 \%$ on the 7 th day of treatment at $750 \mathrm{mg} / \mathrm{kg}$ and on the 5 th day at $1000 \mathrm{mg} / \mathrm{kg}$ in the watery extracts. At a rate of $100 \%$ on the 4 th day at $1000 \mathrm{mg} / \mathrm{kg}$ 
in alcoholic extracts [265]. Potential cryptosporicidal effects have been observed for blueberry with its polyphenolic compounds, cinnamon with its phenolic compounds and onion with its flavonoids and sulfide compounds, garlic with its allicin, mango with its mangiferin, olive pomace with its oleuropein, pomegranate with its polyphenols and tannins and oregano with its carvacrol especially against Cryptosporidium parvum and Cryptosporidium hominis [266]. The anti-Cryptosporidium efficacies of various plant extracts were evaluated in four groups of age-matched neonatal Swiss albino mice. There was a $100 \%$ reduction in Cryptosporidium oocyst excretion in stool and copro-DNA of O. europaea-treated infected mice after 2 weeks. Thus, the plant of O. europaea is a promising natural therapeutic for cryptosporidiosis [267].

A detailed list of antiprotozoal activity of important medicinal plant extract and phytochemicals against foodborne parasites is provided in Table 1. Chemical structures of some of the plants derived bioactive compounds are given in Figure 1.

Table 1. Summary of effects of plant extracts and phytochemicals against foodborne parasites.

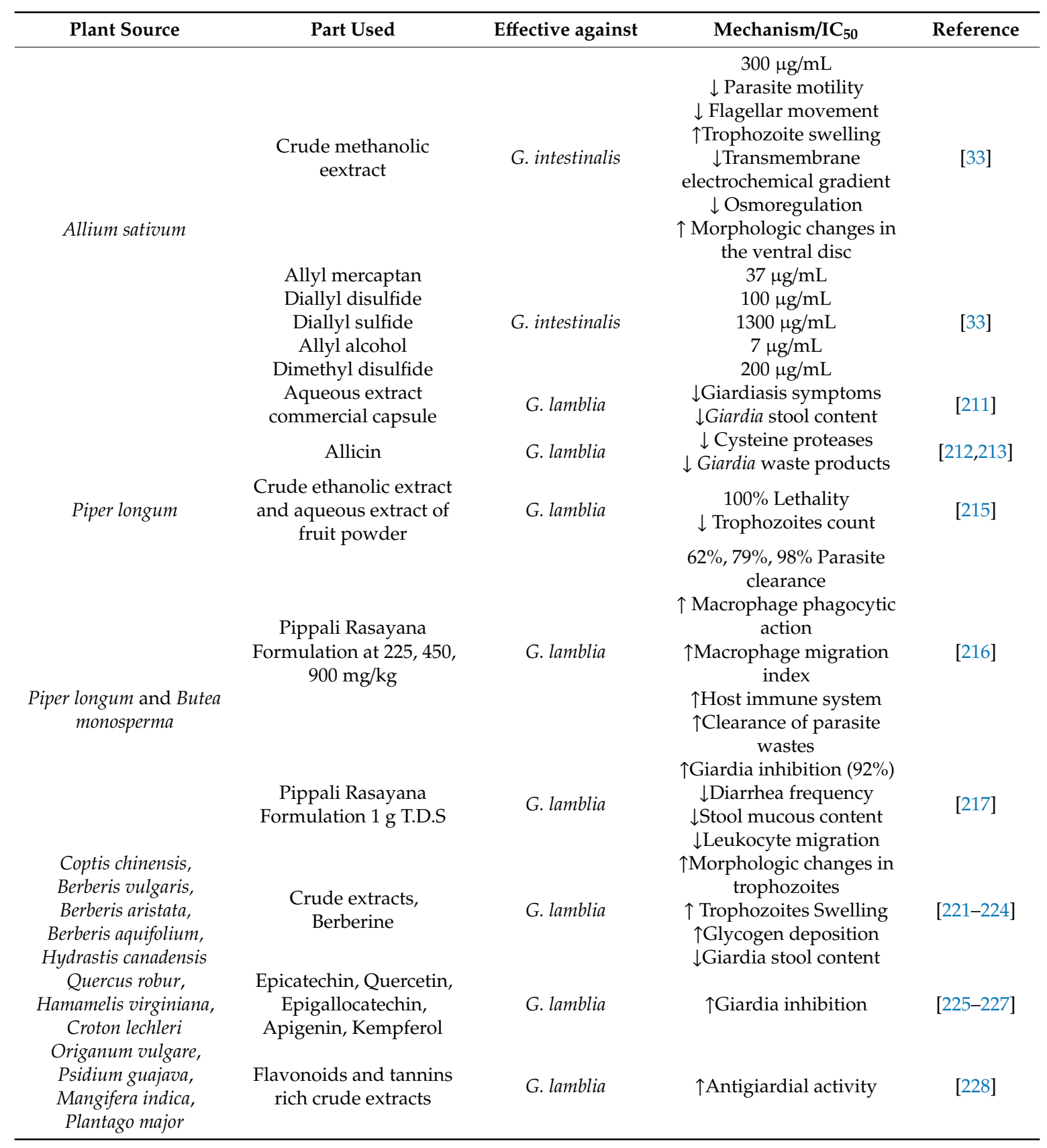


Table 1. Cont.

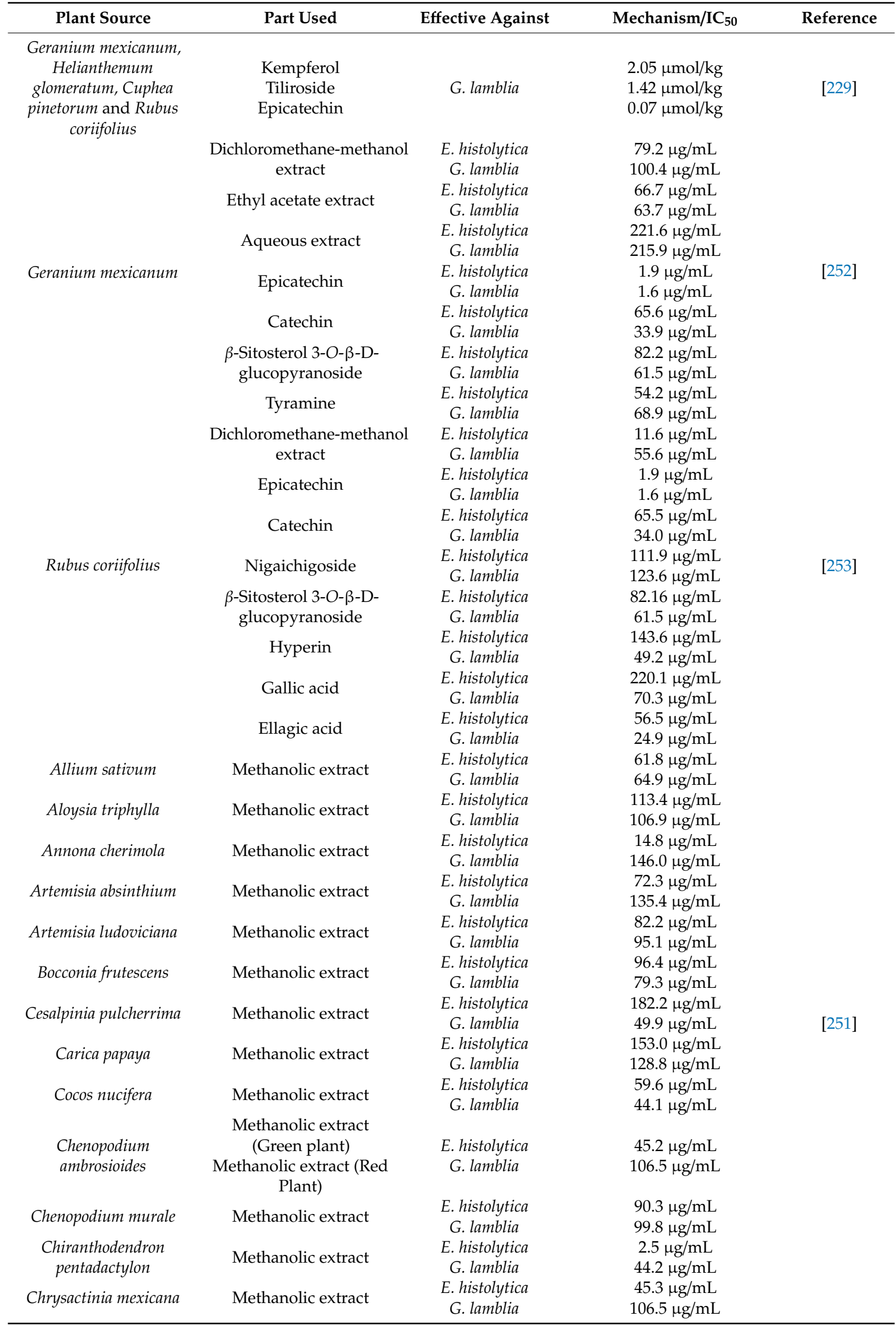


Table 1. Cont.

\begin{tabular}{|c|c|c|c|c|}
\hline Plant Source & Part Used & Effective Against & Mechanism/IC 50 & Reference \\
\hline Dorstenia contrajerva & Methanolic extract & $\begin{array}{l}\text { E. histolytica } \\
\text { G. lamblia }\end{array}$ & $\begin{array}{l}47.1 \mu \mathrm{g} / \mathrm{mL} \\
23.3 \mu \mathrm{g} / \mathrm{mL}\end{array}$ & \\
\hline Dichondra argentea & Methanolic extract & $\begin{array}{l}\text { E. histolytica } \\
\text { G. lamblia }\end{array}$ & $\begin{array}{c}38.3 \mu \mathrm{g} / \mathrm{mL} \\
284.7 \mu \mathrm{g} / \mathrm{mL}\end{array}$ & \\
\hline Geranium mexicanum & Methanolic extract & $\begin{array}{l}\text { E. histolytica } \\
\text { G. lamblia }\end{array}$ & $\begin{array}{l}139.9 \mu \mathrm{g} / \mathrm{mL} \\
267.1 \mu \mathrm{g} / \mathrm{mL}\end{array}$ & \\
\hline Hippocratea excelsa & Methanolic extract & $\begin{array}{l}\text { E. histolytica } \\
\text { G. lamblia }\end{array}$ & $\begin{array}{c}233.2 \mu \mathrm{g} / \mathrm{mL} \\
72.7 \mu \mathrm{g} / \mathrm{mL}\end{array}$ & \\
\hline Lippia alba & Methanolic extract & $\begin{array}{l}\text { E. histolytica } \\
\text { G. lamblia }\end{array}$ & $\begin{array}{r}58.1 \mu \mathrm{g} / \mathrm{mL} \\
109.4 \mu \mathrm{g} / \mathrm{mL}\end{array}$ & \\
\hline Lygodium venustum & Methanolic extract & $\begin{array}{l}\text { E. histolytica } \\
\text { G. lamblia }\end{array}$ & $\begin{array}{l}178.4 \mu \mathrm{g} / \mathrm{mL} \\
74.3 \mu \mathrm{g} / \mathrm{mL}\end{array}$ & \\
\hline Matricaria recutita & Methanolic extract & $\begin{array}{l}\text { E. histolytica } \\
\text { G. lamblia }\end{array}$ & $\begin{array}{l}102.1 \mu \mathrm{g} / \mathrm{mL} \\
67.1 \mu \mathrm{g} / \mathrm{mL}\end{array}$ & \\
\hline Ocimum basilicum & Methanolic extract & $\begin{array}{l}\text { E. histolytica } \\
\text { G. lamblia }\end{array}$ & $\begin{array}{l}41.7 \mu \mathrm{g} / \mathrm{mL} \\
79.4 \mu \mathrm{g} / \mathrm{mL}\end{array}$ & \\
\hline Punica granatum & Methanolic extract & $\begin{array}{l}\text { E. histolytica } \\
\text { G. lamblia }\end{array}$ & $\begin{array}{c}29.5 \mu \mathrm{g} / \mathrm{mL} \\
198.5 \mu \mathrm{g} / \mathrm{mL}\end{array}$ & \\
\hline Ruta chalepensis & Methanolic extract & $\begin{array}{l}\text { E. histolytica } \\
\text { G. lamblia }\end{array}$ & $\begin{array}{l}61.9 \mu \mathrm{g} / \mathrm{mL} \\
37.8 \mu \mathrm{g} / \mathrm{mL}\end{array}$ & \\
\hline Schinus molle & Methanolic extract & $\begin{array}{l}\text { E. histolytica } \\
\text { G. lamblia }\end{array}$ & $\begin{array}{r}82.4 \mu \mathrm{g} / \mathrm{mL} \\
154.7 \mu \mathrm{g} / \mathrm{mL}\end{array}$ & \\
\hline Senna villosa & Methanolic extract & $\begin{array}{l}\text { E. histolytica } \\
\text { G. lamblia }\end{array}$ & $\begin{array}{l}133.1 \mu \mathrm{g} / \mathrm{mL} \\
32.1 \mu \mathrm{g} / \mathrm{mL}\end{array}$ & \\
\hline Thymus vulgaris & Methanolic extract & $\begin{array}{l}\text { E. histolytica } \\
\text { G. lamblia }\end{array}$ & $\begin{array}{l}90.9 \mu \mathrm{g} / \mathrm{mL} \\
68.7 \mu \mathrm{g} / \mathrm{mL}\end{array}$ & \\
\hline Sophora flavescens Torilis & & & $99.7 \%$ & \\
\hline japonica, Ulmus & & & $99.9 \%$ & \\
\hline $\begin{array}{c}\text { macrocarpa, Sinomenium } \\
\text { acutum }\end{array}$ & Alcoholic extracts & T. gondii & $\begin{array}{l}99.8 \% \\
99.7 \%\end{array}$ & [259] \\
\hline Pulsatilla koreana & & & $99.6 \%$ & \\
\hline Sophora flavescens & & & 0.20 & \\
\hline Meliae cortex & & & 0.77 & \\
\hline $\begin{array}{l}\text { Acorus gramineus } \\
\text { Drupteris }\end{array}$ & Methanolic extracts & T. gondii & 0.11 & [261] \\
\hline $\begin{array}{l}\text { Dryopteris crassirnizoma } \\
\text { Glycyrrhiza glabra }\end{array}$ & & & $\begin{array}{l}0.15 \\
0.13\end{array}$ & \\
\hline Zingiber officinale & & & 0.18 & \\
\hline & Ailanthinone & & $0.02 \mu \mathrm{M}$ & \\
\hline & Bruceantin & & $0.01 \mu \mathrm{M}$ & \\
\hline & Bruceine A & & NT & \\
\hline & Bruceine B & & $0.75 \mu \mathrm{M}$ & \\
\hline & Bruceine $\mathrm{C}$ & T. gondii & $0.84 \mu \mathrm{M}$ & [260] \\
\hline & Bruceine D & & $7.56 \mu \mathrm{M}$ & \\
\hline & Brusatol & & $0.17 \mu \mathrm{M}$ & \\
\hline & Glaucarubinone & & $0.37 \mu \mathrm{M}$ & \\
\hline & Quassin & & $11 \mu \mathrm{M}$ & \\
\hline & Ailanthinone & & $0.13 \mu \mathrm{M}$ & \\
\hline & Bruceantin & & $0.03 \mu \mathrm{M}$ & \\
\hline & Bruceine A & & $0.22 \mu \mathrm{M}$ & \\
\hline Brucea javanica & Bruceine B & & $0.63 \mu \mathrm{M}$ & \\
\hline Simarouba amara & Bruceine C & E. nistolytica & $0.49 \mu \mathrm{M}$ & {$[260]$} \\
\hline & Bruceine D & & $0.06 \mu \mathrm{M}$ & \\
\hline & Brusatol & & $0.32 \mu \mathrm{M}$ & \\
\hline & Glaucarubinone & & $1130 \mu \mathrm{M}$ & \\
\hline & Ailanthinone & & $45.44 \mu \mathrm{M}$ & \\
\hline & Bruceantin & & $1.20 \mu \mathrm{M}$ & \\
\hline & Bruceine A & & $8.84 \mu \mathrm{M}$ & \\
\hline & Bruceine B & G intestinalis & NT & {$[2600]$} \\
\hline & Bruceine C & G. intestinalts & NA & {$[\angle 60]$} \\
\hline & Bruceine D & & NA & \\
\hline & Brusatol & & 6. I7 $\mu \mathrm{M}$ & \\
\hline & Glaucarubinone & & $12.42 \mu \mathrm{M}$ & \\
\hline Brucea antidysenterica & Bruceantin & E. histolytica & $0.01 \mu \mathrm{g} / \mathrm{mL}$ & [243] \\
\hline $\begin{array}{l}\text { Brucea javanica, } \\
\text { Simarouba amara }\end{array}$ & $\begin{array}{l}\text { Bruceantin } \\
\text { Glaucarubol }\end{array}$ & E. histolytica & $\begin{array}{c}0.01 \mu \mathrm{g} / \mathrm{mL} \\
5 \mu \mathrm{g} / \mathrm{mL}\end{array}$ & [245] \\
\hline
\end{tabular}


Table 1. Cont.

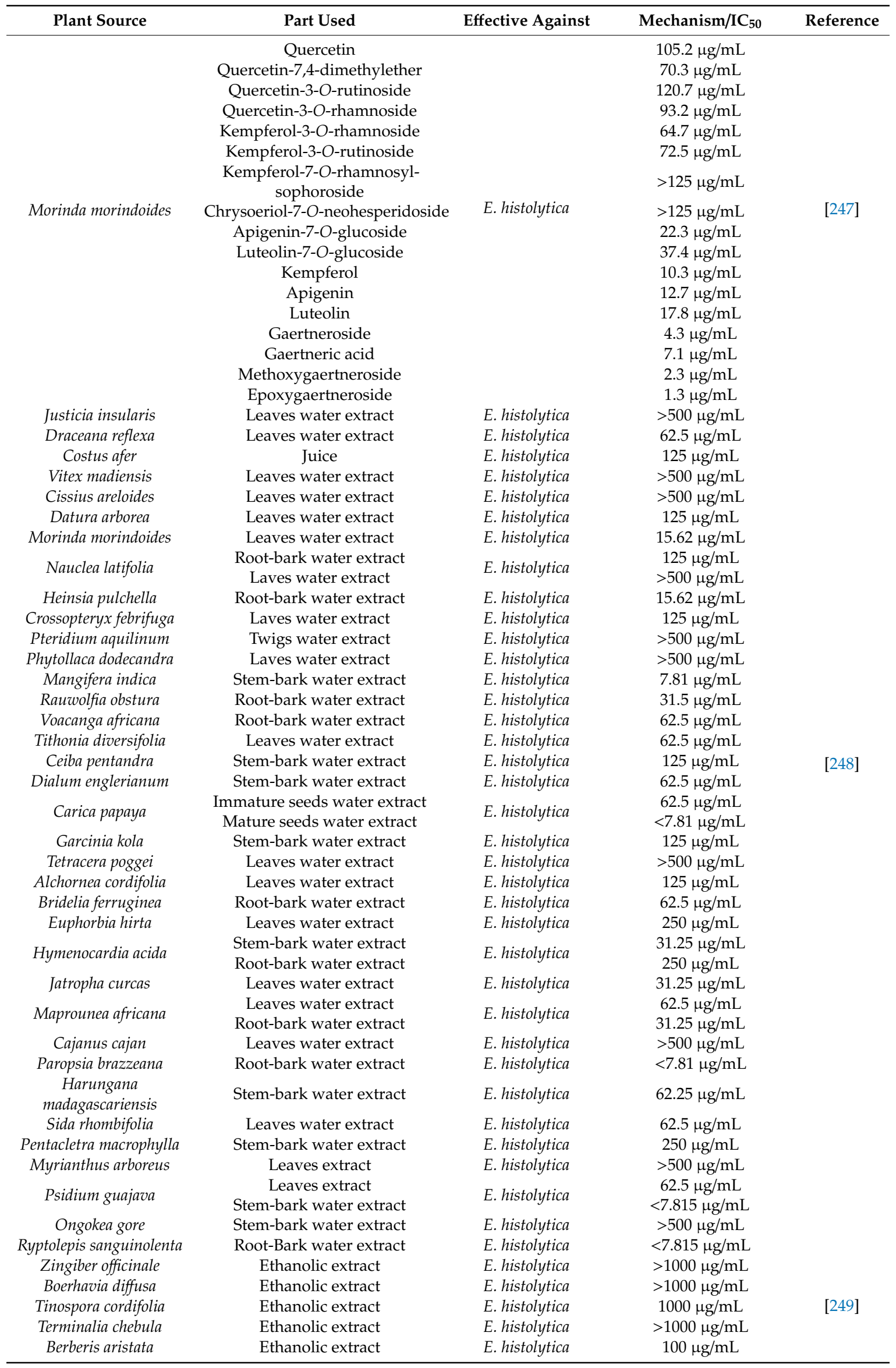


Table 1. Cont.

\begin{tabular}{ccccc}
\hline Plant Source & Part Used & Effective Against & ${\text { Mechanism/ } / \mathrm{IC}_{\mathbf{5 0}}}$ & Reference \\
\hline & Polystachyne A & E. histolytica & $153.8 \mu \mathrm{g} / \mathrm{mL}$ & \\
& G. lamblia & $134.7 \mu \mathrm{g} / \mathrm{mL}$ & \\
& Polystachyne B & E. histolytica & $117.0 \mu \mathrm{g} / \mathrm{mL}$ & \\
& G. lamblia & $107.8 \mu \mathrm{g} / \mathrm{mL}$ & $160.6 \mu \mathrm{g} / \mathrm{mL}$ & [250] \\
Salvia polystachya & E. histolytica & $107.5 \mu \mathrm{g} / \mathrm{mL}$ & \\
& Polystachyne D & G. lamblia & $22.9 \mu \mathrm{g} / \mathrm{mL}$ & \\
& Linearolactone & E. histolytica & $28.2 \mu \mathrm{g} / \mathrm{mL}$ & \\
& Giardia lamblia & $27.7 \mu \mathrm{g} / \mathrm{mL}$ & \\
\hline
\end{tabular}

NT: not tested, NA: not active, $\uparrow:$ Increase/activate, $\downarrow$ : decrease/inhibit, $\leftrightarrow$ : no effect/not modulate, CDT: cytolethal distending toxin, EO: essential oils.
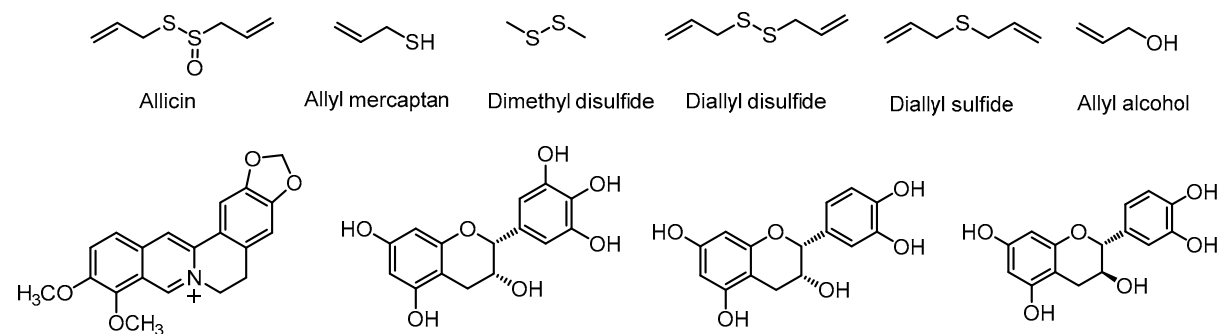

Berberine

(-)-Epigallocatechin

(-)-Epicatechin

(+)-Catechin<smiles></smiles>

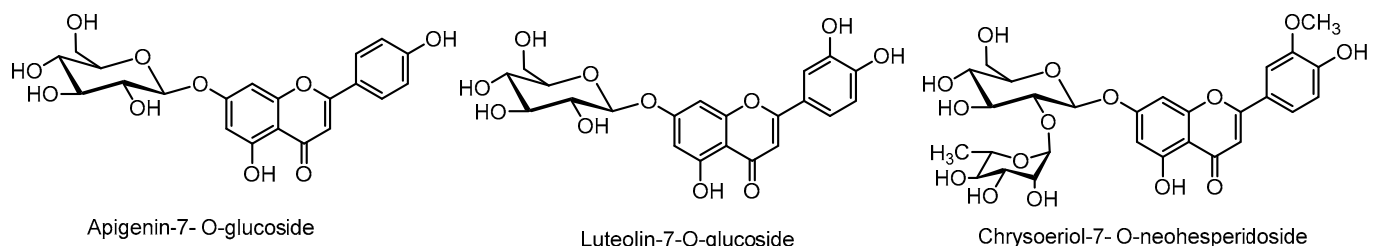<smiles>COc1cc(O)c2c(=O)c(O)c(-c3ccc(OC)c(O)c3)oc2c1</smiles>

Quercetin-7,4-dimethylether

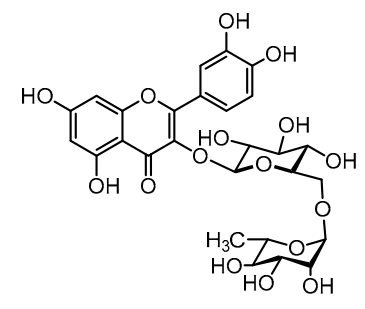

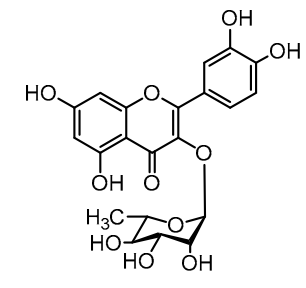<smiles>NCCc1ccc(O)cc1</smiles>

Quercetin-3-O-rutinoside

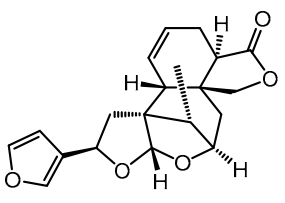

Polystachyne A

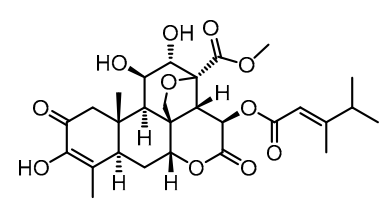

Bruceantin

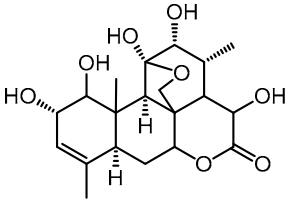

Glaucarubol

Figure 1. Chemical structures of some of the phytochemicals discussed in this manuscript. 


\section{Mechanisms of Antimicrobial Activity}

Various mechanisms have been reported for the antimicrobial activities of medicinal plants and isolated natural antimicrobials. These natural products affect those pathways of macromolecular metabolism which are proven targets for antibiotic intervention. Among the existing antibacterial agents, it is clear that protein and cell wall biosynthesis are the targets of the widest variety of natural products [34]. The pathways of macromolecular metabolism as antimicrobial targets of natural products include inhibition of protein synthesis, inhibition of cell wall synthesis, disruption of membrane integrity, inhibition of RNA synthesis, inhibition of DNA synthesis, dysfunction of microtubules, inhibition of lipid synthesis, inhibition of cell division, dysfunction in ion uptake, reduction in protein secretion, dysfunction of RNA processing and inhibition of DNA methylation. These mechanisms have been investigated for the antimicrobial properties of medicinal plants and natural products including Hemidesmus indicus (L.) R. Br. ex Schult., Leucas aspera (Willd.) Link, Plumbago zeylanica L., Tridax procumbens (L.) L. [268], Syzygium cumini (L.) Skeels [269], Combretum albidum G.Don, Hibiscus acetosella Welw. ex Hiern, Hibiscus cannabinus L., Hibiscus furcatus Willd., Punica granatum L. and Tamarindus indica L. [270], 5,6,7-trihydroxyflavone (baicalein) [271], flavones [272], Hibiscus sabdariffa, Rosmarinus officinalis, Syzygium aromaticum, Thymus vulgaris [273], linalyl acetate, (+)menthol, thymol [274], Origanum vulgare [275], essential oils [276], caffeine [277], allspice oil, lemongrass oil, citral [278], alkaloids [279], Boerhaavia diffusa [280], paeonol (PA) and 1,2,3,4,6-penta-O-galloyl- $\beta$-D-glucopyranose (PGG) from Paeonia lactiflora Pall. [281], Aristolochia bracteolata Lam. [282], Rhizophora apiculate Blume, Phyllanthus niruri L., Scutellaria baicalensis Georgi, Geum japonicum L. and Momordica charantia L. [283]. Plants being mixture of numerous compounds can act on several targets like, inhibition of bacterial cell wall synthesis, protein synthesis and interference with microbial metabolic pathways. Hence, as a whole, the activity of crude extracts may be due to more than one antibacterial mechanism. Further, different compounds in the extract can act synergistically as well as can antagonize the effect of each other depending upon their respective concentrations. Considering the presence of large number of chemical compounds present in the extracts of medicinal plants, it is most likely that their antimicrobial activity can be attributed to more than a single specific antimicrobial mechanism.

\section{Persisting Challenges}

However, many plant extracts and their isolated phytochemicals have been reported to show potent activity against foodborne illness causing agents, there have not been detailed studies about their mechanism using in vivo studies. As the systematic treatment, use of oral rehydration salts and antibiotics are also of great concern for their use in foodborne illness in children and their efficacies [17], alternative therapies like herbal extracts and compounds should be used with proper caution and with the support of scientific evidence regarding the other dosage forms of these herbal products. Human gut microbiota plays a vital role in sustaining gastrointestinal health via inhibition of pathogenic microbes. The use of broad-spectrum antibiotics causes inhibition of normal flora beside pathogenic bacteria, thus provide the opportunity to other pathogens and secondary infections emerge $[284,285]$. On the other hand, herbal products like tea and many herbs and vegetables are also reported to be the source of foodborne microorganisms [286,287]. Herbal products contaminated with mycotoxins, bacterial toxins, as well as bacterial strains are reported to cause foodborne infections. For instance, herbs contaminated with Salmonella is a major cause of foodborne infections in North America and Europe [286]. Subsequently, several approaches were adopted to decontaminate these products including irradiation which effectively eradicate Salmonella, S. aureus, Comphylobacter sp., Listeria and E. coli without affecting nutritional properties of these products [288].

Natural product research has broadly emerged into two major fields including ethnopharmacology and toxicology. However, both strategies were successful regarding the discovery of numerous drugs against several diseases, yet the development of antimicrobial agents from these sources is limited [289]. To augment the development of antimicrobial agents from the herbal source it is important to elucidate exact molecular antimicrobial mechanisms of these products. This information will enable researchers 
not only to have better control of these microbes but will use modern technologies to synthesize more potent and effective derivatives. Moreover, studies regarding the efficacy of these agents in combination with other herbs and drugs is limited. For instance, a combination of several EOs in combined form does not produce the synergistic antimicrobial effect and subsequently their use as a food preservative is limited. These agents can also interact with food ingredients which significantly affect their quality. Like, EOs beside their great beneficial effects has limited efficacy as a food preservative due to the intense aroma and toxicity issues. EOs used as preservatives in food are reported to change organoleptic properties of foodstuff and their higher doses can produce severe toxicological responses [290,291].

\section{Conclusions}

Foodborne diseases are one of the main causes of morbidity and mortality, especially in low-income countries having poor sanitation and inadequate healthcare facilities. Several plant extracts and phytochemicals including catechin, epigallocatechin, apigenin, kempferol, berberine, tiliroside and quercetin were found to be highly effective to control the growth of these foodborne pathogens causing infections in in vitro systems. Various mechanisms have been reported for the antimicrobial activities of medicinal plants and they affect those pathways of macromolecular metabolism which are the proven targets for antibiotic intervention. Medicinal plants can impact more than a single specific antimicrobial target as they contain a large number of biochemical phytoconstituents. Once utilized, natural products with antimicrobial properties can be effective for the prevention and treatment of foodborne diseases and can increase the shelf life of food products. However, most of the studies covered in this review are performed using in vitro assays. Further detailed in vivo studies for exploration of effectiveness and mechanism of their activities are necessary. Along with that, most of these studies were performed in the in vitro systems without the addition of food, simulated gastric and/or intestinal juice. Various such factors may alter the activity of these extracts and compounds when used in complex biologic systems such as in vivo and human studies. Future studies should also focus on the pharmacokinetic and toxicological aspects of plant extracts and phytochemicals.

Author Contributions: F.U. (Farhat Ullah), F.U. (Farman Ullah), M.A., A.A.-D., A.S., I.H. conceived the idea, performed literature review, data collection, interpretation and manuscript preparation. M.S., Z.Y., A.A.-D. and H.P.D. revised the manuscript. All authors have read and agreed to the published version of the manuscript.

Funding: There is no particular funding to support this research.

Conflicts of Interest: The authors declare no conflicts of interest.

\section{References}

1. Rane, S. Street vended food in developing world: Hazard analyses. Indian J. Microbiol. 2011, 51, $100-106$. [CrossRef]

2. Nout, M. Fermented foods and food safety. Food Res. Int. 1994, 27, 291-298. [CrossRef]

3. Ayaz, M.; Junaid, M.; Subhan, F.; Ullah, F.; Sadiq, A.; Ahmad, S.; Imran, M.; Kamal, Z.; Hussain, S.; Shah, S.M. Heavy metals analysis, phytochemical, phytotoxic and anthelmintic investigations of crude methanolic extract, subsequent fractions and crude saponins from Polygonum hydropiper L. BMC Complement. Altern. Med. 2014, 14, 465. [CrossRef] [PubMed]

4. Scallan, E.; Hoekstra, R.M.; Angulo, F.J.; Tauxe, R.V.; Widdowson, M.-A.; Roy, S.L.; Jones, J.L.; Griffin, P.M. Foodborne illness acquired in the United States-Major pathogens. Emerg. Infect. Dis. 2011, 17, 7. [CrossRef] [PubMed]

5. Kumagai, Y.; Gilmour, S.; Ota, E.; Momose, Y.; Onishi, T.; Bilano, F.; Luanni, V.; Kasuga, F.; Sekizaki, T.; Shibuya, K. Estimating the burden of foodborne diseases in Japan. Bull. World Health Organ. 2015, 93, 540-549. [CrossRef]

6. Olsen, S.J.; MacKinon, L.C.; Goulding, J.S.; Bean, N.H.; Slutsker, L. Surveillance for Foodborne-Disease Outbreaks, United States, 1993-1997. MMWR CDC Surveill. Summ. 2000, 49, 1-62. [PubMed]

7. Park, M.S.; Kim, Y.S.; Lee, S.H.; Kim, S.H.; Park, K.H.; Bahk, G.J. Estimating the burden of foodborne disease, South Korea, 2008-2012. Foodborne Pathog. Dis. 2015, 12, 207-213. [CrossRef] 
8. Available online: https://www.who.int/activities/estimating-the-burden-of-foodborne-diseases (accessed on 26 May 2020).

9. Buchanan, R.L.; Smith, J.L.; Long, W. Microbial risk assessment: Dose-response relations and risk characterization. Int. J. Food Microbiol. 2000, 58, 159-172. [CrossRef]

10. Xiao, L.; Ryan, U.; Feng, Y. Biology of Foodborne Parasites; CRC Press: Boca Raton, FL, USA, 2015 ; Volume 1.

11. Dei-Cas, E.; Aliouat, C.-M.; Certad, G.; Creusy, C.; Guyot, K. Infectious Forms of Parasites in Food: Man Embedded in Ecosystems. In Detection of Bacteria, Viruses, Parasites and Fungi; Springer: Dordrecht, The Netherlands, 2010; pp. 299-332.

12. Hernández-Cortez, C.; Palma-Martínez, I.; Gonzalez-Avila, L.U.; Guerrero-Mandujano, A.; Solís, R.C.; Castro-Escarpulli, G. Food Poisoning Caused by Bacteria (Food Toxins). In Poisoning_From Specific Toxic Agents to Novel Rapid and Simplified Techniques for Analysis; IntechOpen Limited: London, UK, 2017; pp. 33-72.

13. Walsh, C.; Fanning, S. Antimicrobial resistance in foodborne pathogens-A cause for concern? Curr. Drug Targets 2008, 9, 808-815. [CrossRef]

14. Slutsker, L.; Altekruse, S.F.; Swerdlow, D.L. Foodborne diseases: Emerging pathogens and trends. Infect. Dis. Clin. 1998, 12, 199-216. [CrossRef]

15. Abd El-Baky, H.H.; El-Baroty, G.S. The Potential Use of Microalgal Carotenoids as Dietary Supplements and Natural Preservative Ingredients. J. Aquat. Food Prod. Technol. 2013, 22, 392-406. [CrossRef]

16. Msagati, T.A. The Chemistry of Food Additives and Preservatives; John Wiley \& Sons: Hoboken, NJ, USA, 2012.

17. Switaj, T.L.; Winter, K.J.; Christensen, S.R. Diagnosis and management of foodborne illness. Am. Fam. Physician 2015, 92, 358-365.

18. Ayaz, M.; Subhan, F.; Sadiq, A.; Ullah, F.; Ahmed, J.; Sewell, R. Cellular efflux transporters and the potential role of natural products in combating efflux mediated drug resistance. Front. Biosci. (Landmark Ed.) 2017, 22, 732-756. [CrossRef]

19. Ayaz, M.; Subhan, F.; Ahmed, J.; Khan, A.-u.; Ullah, F.; Ullah, I.; Ali, G.; Hussain, S. Sertraline enhances the activity of antimicrobial agents against pathogens of clinical relevance. J. Biol. Res. Thessalon. 2015, 22, 4. [CrossRef]

20. Ayaz, M.; Subhan, F.; Ahmed, J.; Khan, A.-U.; Ullah, F.; Sadiq, A.; Syed, N.; Ullah, I.; Hussain, S. Citalopram and venlafaxine differentially augments antimicrobial properties of antibiotics. Acta Pol. Pharm. Drug Res. 2015, 72, 1269-1278.

21. Shahid, M.; Subhan, F.; Ahmad, N.; Ullah, I. A bacosides containing Bacopa monnieri extract alleviates allodynia and hyperalgesia in the chronic constriction injury model of neuropathic pain in rats. BMC Complement. Altern. Med. 2017, 17, 293. [CrossRef]

22. Shahid, M.; Subhan, F.; Ullah, I.; Ali, G.; Alam, J.; Shah, R. Beneficial effects of Bacopa monnieri extract on opioid induced toxicity. Heliyon 2016, 2, e00068. [CrossRef] [PubMed]

23. Aman, U.; Subhan, F.; Shahid, M.; Akbar, S.; Ahmad, N.; Ali, G.; Fawad, K.; Sewell, R.D. Passiflora incarnata attenuation of neuropathic allodynia and vulvodynia apropos GABA-ergic and opioidergic antinociceptive and behavioural mechanisms. BMC Complement. Altern. Med. 2016, 16, 77. [CrossRef]

24. Ullah, I.; Subhan, F.; Alam, J.; Shahid, M.; Ayaz, M. Suppression of cisplatin-induced vomiting by Cannabis sativa in pigeons: Neurochemical evidences. Front. Pharmacol. 2018, 9, 231. [CrossRef] [PubMed]

25. Ayaz, M.; Sadiq, A.; Junaid, M.; Ullah, F.; Subhan, F.; Ahmed, J. Neuroprotective and anti-aging potentials of essential oils from aromatic and medicinal plants. Front. Aging Neurosci. 2017, 9, 168. [CrossRef]

26. Ovais, M.; Ayaz, M.; Khalil, A.T.; Shah, S.A.; Jan, M.S.; Raza, A.; Shahid, M.; Shinwari, Z.K. HPLC-DAD finger printing, antioxidant, cholinesterase, and $\alpha$-glucosidase inhibitory potentials of a novel plant Olax nana. BMC Complement. Altern. Med. 2018, 18, 1. [CrossRef] [PubMed]

27. Odeyemi, O.A.; Sani, N.A. Antibiotic resistance and burden of foodborne diseases in developing countries. Future Sci. 2016, 2, FSO139. [CrossRef] [PubMed]

28. Grace, D. Food safety in low and middle income countries. Int. J. Environ. Res. Public Health 2015, 12, 10490-10507. [CrossRef] [PubMed]

29. Ayaz, M.; Ullah, F.; Sadiq, A.; Ullah, F.; Ovais, M.; Ahmed, J.; Devkota, H.P. Synergistic interactions of phytochemicals with antimicrobial agents: Potential strategy to counteract drug resistance. Chem. Biol. Interact. 2019, 308, 294-303. [CrossRef]

30. Smid, E.J.; Gorris, L.G. Natural antimicrobials for food preservation. In Handbook of Food Preservation; CRC Press: Boca Raton, FL, USA, 2007; pp. 237-358. 
31. Ehiri, J.E.; Morris, G. Food safety control strategies: A critical review of traditional approaches. Int. J. Environ. Health Res. 1994, 4, 254-263. [CrossRef]

32. Castillo, S.L.; Heredia, N.; Contreras, J.F.; Garcia, S. Extracts of edible and medicinal plants in inhibition of growth, adherence, and cytotoxin production of Campylobacter jejuni and Campylobacter coli. J. Food Sci. 2011, 76, M421-M426. [CrossRef]

33. Harris, J.C.; Plummer, S.; Turner, M.P.; Lloyd, D. The microaerophilic flagellate Giardia intestinalis: Allium sativum (garlic) is an effective antigiardial. Microbiology 2000, 146, 3119-3127. [CrossRef]

34. Silver, L.; Bostian, K. Screening of natural products for antimicrobial agents. Eur. J. Clin. Microbiol. Infect. Dis. 1990, 9, 455-461. [CrossRef]

35. Nachamkin, I.; Szymanski, C.M.; Blaser, M.J. Campylobacter, 3rd ed.; American Society for Microbiology Press: Washington, DC, USA, 2008.

36. Kirk, M.D.; Pires, S.M.; Black, R.E.; Caipo, M.; Crump, J.A.; Devleesschauwer, B.; Dopfer, D.; Fazil, A.; Fischer-Walker, C.L.; Hald, T.; et al. World Health Organization Estimates of the Global and Regional Disease Burden of 22 Foodborne Bacterial, Protozoal, and Viral Diseases, 2010: A Data Synthesis. PLoS Med. 2015, 12, e1001921. [CrossRef]

37. Cha, W.; Mosci, R.E.; Wengert, S.L.; Venegas Vargas, C.; Rust, S.R.; Bartlett, P.C.; Grooms, D.L.; Manning, S.D. Comparing the Genetic Diversity and Antimicrobial Resistance Profiles of Campylobacter jejuni Recovered from Cattle and Humans. Front. Microbiol. 2017, 8, 818. [CrossRef]

38. Szczepanska, B.; Andrzejewska, M.; Spica, D.; Klawe, J.J. Prevalence and antimicrobial resistance of Campylobacter jejuni and Campylobacter coli isolated from children and environmental sources in urban and suburban areas. BMC Microbiol. 2017, 17, 80. [CrossRef]

39. Dholvitayakhun, A.; Cushnie, T.P.; Trachoo, N. Antibacterial activity of three medicinal Thai plants against Campylobacter jejuni and other foodborne pathogens. Nat. Prod. Res. 2012, 26, 356-363. [CrossRef] [PubMed]

40. Singh, G.; Passsari, A.K.; Leo, V.V.; Mishra, V.K.; Subbarayan, S.; Singh, B.P.; Kumar, B.; Kumar, S.; Gupta, V.K.; Lalhlenmawia, H.; et al. Evaluation of Phenolic Content Variability along with Antioxidant, Antimicrobial, and Cytotoxic Potential of Selected Traditional Medicinal Plants from India. Front. Plant Sci. 2016, 7, 407. [CrossRef]

41. Ouahouo, B.M.; Azebaze, A.G.; Meyer, M.; Bodo, B.; Fomum, Z.T.; Nkengfack, A.E. Cytotoxic and antimicrobial coumarins from Mammea africana. Ann. Trop. Med. Parasitol. 2004, 98, 733-739. [CrossRef]

42. Canning, C.; Sun, S.; Ji, X.; Gupta, S.; Zhou, K. Antibacterial and cytotoxic activity of isoprenylated coumarin mammea A/AA isolated from Mammea africana. J. Ethnopharmacol. 2013, 147, 259-262. [CrossRef]

43. Fais, T.; Delmas, J.; Serres, A.; Bonnet, R.; Dalmasso, G. Impact of CDT Toxin on Human Diseases. Toxins 2016, 8, 220. [CrossRef]

44. Sanchez, E.; Garcia, S.; Heredia, N. Extracts of edible and medicinal plants damage membranes of Vibrio cholerae. Appl. Environ. Microbiol. 2010, 76, 6888-6894. [CrossRef]

45. Upadhyay, A.; Arsi, K.; Wagle, B.R.; Upadhyaya, I.; Shrestha, S.; Donoghue, A.M.; Donoghue, D.J. Trans-Cinnamaldehyde, Carvacrol, and Eugenol Reduce Campylobacter jejuni Colonization Factors and Expression of Virulence Genes in Vitro. Front. Microbiol. 2017, 8, 713. [CrossRef] [PubMed]

46. Kovacs, J.K.; Felso, P.; Makszin, L.; Papai, Z.; Horvath, G.; Abraham, H.; Palkovics, T.; Boszormenyi, A.; Emody, L.; Schneider, G. Antimicrobial and Virulence-Modulating Effects of Clove Essential Oil on the Foodborne Pathogen Campylobacter jejuni. Appl. Environ. Microbiol. 2016, 82, 6158-6166. [CrossRef] [PubMed]

47. Friedman, M.; Henika, P.R.; Mandrell, R.E. Bactericidal activities of plant essential oils and some of their isolated constituents against Campylobacter jejuni, Escherichia coli, Listeria monocytogenes, and Salmonella enterica. J. Food Prot. 2002, 65, 1545-1560. [CrossRef] [PubMed]

48. Fisher, K.; Phillips, C.A. The effect of lemon, orange and bergamot essential oils and their components on the survival of Campylobacter jejuni, Escherichia coli O157, Listeria monocytogenes, Bacillus cereus and Staphylococcus aureus in vitro and in food systems. J. Appl. Microbiol. 2006, 101, 1232-1240. [CrossRef] [PubMed]

49. Kurekci, C.; Padmanabha, J.; Bishop-Hurley, S.L.; Hassan, E.; Al Jassim, R.A.; McSweeney, C.S. Antimicrobial activity of essential oils and five terpenoid compounds against Campylobacter jejuni in pure and mixed culture experiments. Int. J. Food Microbiol. 2013, 166, 450-457. [CrossRef] 
50. Rattanachaikunsopon, P.; Phumkhachorn, P. Potential of coriander (Coriandrum sativum) oil as a natural antimicrobial compound in controlling Campylobacter jejuni in raw meat. Biosci. Biotechnol. Biochem. 2010, 74, 31-35. [CrossRef]

51. Rossi, P.G.; Bao, L.; Luciani, A.; Panighi, J.; Desjobert, J.M.; Costa, J.; Casanova, J.; Bolla, J.M.; Berti, L. (E)-Methylisoeugenol and elemicin: Antibacterial components of Daucus carota L. essential oil against Campylobacter jejuni. J. Agric. Food Chem. 2007, 55, 7332-7336. [CrossRef]

52. Hernandez-Ochoa, L.; Aguirre-Prieto, Y.B.; Nevarez-Moorillon, G.V.; Gutierrez-Mendez, N.; Salas-Munoz, E. Use of essential oils and extracts from spices in meat protection. J. Food Sci. Technol. 2014, 51, 957-963. [CrossRef]

53. Lu, X.; Rasco, B.A.; Jabal, J.M.; Aston, D.E.; Lin, M.; Konkel, M.E. Investigating antibacterial effects of garlic (Allium sativum) concentrate and garlic-derived organosulfur compounds on Campylobacter jejuni by using Fourier transform infrared spectroscopy, Raman spectroscopy, and electron microscopy. Appl. Environ. Microbiol. 2011, 77, 5257-5269. [CrossRef] [PubMed]

54. Smith-Palmer, A.; Stewart, J.; Fyfe, L. Antimicrobial properties of plant essential oils and essences against five important food-borne pathogens. Lett. Appl. Microbiol. 1998, 26, 118-122. [CrossRef]

55. Ozogul, Y.; Kuley, E.; Ucar, Y.; Ozogul, F. Antimicrobial Impacts of Essential Oils on Food Borne-Pathogens. Recent Pat. Food Nutr. Agric. 2015, 7, 53-61. [CrossRef]

56. Sela, F.; Karapandzova, M.; Stefkov, G.; Cvetkovikj, I.; Kulevanova, S. Chemical composition and antimicrobial activity of essential oils of Juniperus excelsa Bieb. (Cupressaceae) grown in R. Macedonia. Pharmacogn. Res. 2015, 7, 74-80. [CrossRef]

57. Silva, O.; Duarte, A.; Pimentel, M.; Viegas, S.; Barroso, H.; Machado, J.; Pires, I.; Cabrita, J.; Gomes, E. Antimicrobial activity of Terminalia macroptera root. J. Ethnopharmacol. 1997, 57, 203-207. [CrossRef]

58. Samie, A.; Obi, C.L.; Lall, N.; Meyer, J.J. In-vitro cytotoxicity and antimicrobial activities, against clinical isolates of Campylobacter species and Entamoeba histolytica, of local medicinal plants from the Venda region, in South Africa. Ann. Trop. Med. Parasitol. 2009, 103, 159-170. [CrossRef] [PubMed]

59. Paulo, A.; Pimentel, M.; Viegas, S.; Pires, I.; Duarte, A.; Cabrita, J.; Gomes, E.T. Cryptolepis sanguinolenta activity against diarrhoeal bacteria. J. Ethnopharmacol. 1994, 44, 73-77. [CrossRef]

60. Jarriyawattanachaikul, W.; Chaveerach, P.; Chokesajjawatee, N. Antimicrobial Activity of Thai-herbal Plants against Food-borne Pathogens E. coli, S. aureus and C. jejuni. Agric. Agric. Sci. Procedia 2016, 11, $20-24$. [CrossRef]

61. Sreeramulu, G.; Zhu, Y.; Knol, W. Kombucha fermentation and its antimicrobial activity. J. Agric. Food Chem. 2000, 48, 2589-2594. [CrossRef] [PubMed]

62. Diker, K.S.; Akan, M.; Hascelik, G.; Yurdakök, M. The bactericidal activity of tea against Campylobacter jejuni and Campylobacter coli. Lett. Appl. Microbiol. 1991, 12, 34-35. [CrossRef]

63. Aslim, B.; Yucel, N. In vitro antimicrobial activity of essential oil from endemic Origanum minutiflorum on ciprofloxacin-resistant Campylobacter spp. Food Chem. 2008, 107, 602-606. [CrossRef]

64. Kurekci, C.; Bishop-Hurley, S.L.; Vercoe, P.E.; Durmic, Z.; Al Jassim, R.A.; McSweeney, C.S. Screening of Australian plants for antimicrobial activity against Campylobacter jejuni. Phytother. Res. 2012, 26, 186-190. [CrossRef]

65. Welkos, S.; Schreiber, M.; Baer, H. Identification of Salmonella with the O-1 bacteriophage. Appl. Environ. Microbiol. 1974, 28, 618-622. [CrossRef]

66. Letellier, A.; Messier, S.; Quessy, S. Prevalence of Salmonella spp. and Yersinia enterocolitica in finishing swine at Canadian abattoirs. J. Food Prot. 1999, 62, 22-25. [CrossRef]

67. Robinson, R. Salmonella infection: Diagnosis and control. N. Z. Vet. J. 1970, 18, 259-277. [CrossRef]

68. Thorns, C. Bacterial food-borne zoonoses. Rev. Sci. Et Tech. Off. Int. Des Epizoot. 2000, 19, 226-239. [CrossRef]

69. Salmonella-A Dangerous Foodborne Pathogen; Mahmoud, B.S.M. (Ed.) InTechOpen Limited: London, UK, 2016.

70. Sadiq, M.B.; Tarning, J.; Aye Cho, T.Z.; Anal, A.K. Antibacterial Activities and Possible Modes of Action of Acacia nilotica (L.) Del. against Multidrug-Resistant Escherichia coli and Salmonella. Molecules 2017, $22,47$. [CrossRef]

71. Khan, R.; Islam, B.; Akram, M.; Shakil, S.; Ahmad, A.A.; Ali, S.M.; Siddiqui, M.; Khan, A. Antimicrobial Activity of Five Herbal Extracts Against Multi Drug Resistant (MDR) Strains of Bacteria and Fungus of Clinical Origin. Molecules 2009, 14, 586. [CrossRef] [PubMed] 
72. Zhao, Y.; Chen, M.; Zhao, Z.; Yu, S. The antibiotic activity and mechanisms of sugarcane (Saccharum officinarum L.) bagasse extract against food-borne pathogens. Food Chem. 2015, 185, 112-118. [CrossRef] [PubMed]

73. Bisi-Johnson, M.A.; Obi, C.L.; Samuel, B.B.; Eloff, J.N.; Okoh, A.I. Antibacterial activity of crude extracts of some South African medicinal plants against multidrug resistant etiological agents of diarrhoea. BMC Complement. Altern. Med. 2017, 17, 321. [CrossRef] [PubMed]

74. Elisha, I.L.; Botha, F.S.; McGaw, L.J.; Eloff, J.N. The antibacterial activity of extracts of nine plant species with good activity against Escherichia coli against five other bacteria and cytotoxicity of extracts. BMC Complement. Altern. Med. 2017, 17, 133. [CrossRef] [PubMed]

75. Dzoyem, J.P.; Melong, R.; Tsamo, A.T.; Tchinda, A.T.; Kapche, D.G.; Ngadjui, B.T.; McGaw, L.J.; Eloff, J.N. Cytotoxicity, antimicrobial and antioxidant activity of eight compounds isolated from Entada abyssinica (Fabaceae). BMC Res. Notes 2017, 10, 118. [CrossRef]

76. Rahman, M.A.; Imran, T.B.; Islam, S. Antioxidative, antimicrobial and cytotoxic effects of the phenolics of Leea indica leaf extract. Saudi J. Biol. Sci. 2013, 20, 213-225. [CrossRef]

77. Razwinani, M.; Tshikalange, T.E.; Motaung, S.C. Antimicrobial and anti-inflammatory activities of Pleurostylia capensis Turcz (Loes) (Celastraceae). Afr. J. Tradit Complement. Altern Med. 2014, 11, 452-457. [CrossRef]

78. Tanih, N.F.; Ndip, R.N. Evaluation of the Acetone and Aqueous Extracts of Mature Stem Bark of Sclerocarya birrea for Antioxidant and Antimicrobial Properties. Evid. Based Complement. Altern. Med. 2012, 2012, 834156. [CrossRef]

79. Gull, I.; Sohail, M.; Aslam, M.S.; Amin Athar, M. Phytochemical, toxicological and antimicrobial evaluation of Lawsonia inermis extracts against clinical isolates of pathogenic bacteria. Ann. Clin. Microbiol. Antimicrob. 2013, 12, 36. [CrossRef]

80. Shrestha, S.; Subaramaihha, S.R.; Subbaiah, S.G.; Eshwarappa, R.S.; Lakkappa, D.B. Evaluating the antimicrobial activity of methonolic extract of Rhus succedanea leaf gall. Bioimpacts 2013, 3, 195-198. [CrossRef] [PubMed]

81. Stojanovic, G.; Radulovic, N.; Hashimoto, T.; Palic, R. In vitro antimicrobial activity of extracts of four Achillea species: The composition of Achillea clavennae L. (Asteraceae) extract. J. Ethnopharmacol. 2005, 101, 185-190. [CrossRef] [PubMed]

82. Ozbay, H.; Alim, A. Antimicrobial activity of some water plants from the northeastern Anatolian region of Turkey. Molecules 2009, 14, 321-328. [CrossRef] [PubMed]

83. Mbosso Teinkela, J.E.; Assob Nguedia, J.C.; Meyer, F.; Vouffo Donfack, E.; Lenta Ndjakou, B.; Ngouela, S.; Tsamo, E.; Adiogo, D.; Guy Blaise Azebaze, A.; Wintjens, R. In vitro antimicrobial and anti-proliferative activities of plant extracts from Spathodea campanulata, Ficus bubu, and Carica papaya. Pharm. Biol. 2016, 54, 1086-1095. [CrossRef]

84. Assob, J.C.; Kamga, H.L.; Nsagha, D.S.; Njunda, A.L.; Nde, P.F.; Asongalem, E.A.; Njouendou, A.J.; Sandjon, B.; Penlap, V.B. Antimicrobial and toxicological activities of five medicinal plant species from Cameroon traditional medicine. BMC Complement. Altern. Med. 2011, 11, 70. [CrossRef]

85. Fu, L.; Lu, W.; Zhou, X. Phenolic Compounds and In Vitro Antibacterial and Antioxidant Activities of Three Tropic Fruits: Persimmon, Guava, and Sweetsop. BioMed Res. Int. 2016, 2016, 4287461. [CrossRef] [PubMed]

86. Liu, H.; Wang, Q.; Liu, Y.; Chen, G.; Cui, J. Antimicrobial and antioxidant activities of Cichorium intybus root extract using orthogonal matrix design. J. Food Sci. 2013, 78, M258-M263. [CrossRef]

87. Onivogui, G.; Diaby, M.; Chen, X.; Zhang, H.; Kargbo, M.R.; Song, Y. Antibacterial and antifungal activities of various solvent extracts from the leaves and stem bark of Anisophyllea laurina R. Br ex Sabine used as traditional medicine in Guinea. J. Ethnopharmacol. 2015, 168, 287-290. [CrossRef]

88. Benevides Bahiense, J.; Marques, F.M.; Figueira, M.M.; Vargas, T.S.; Kondratyuk, T.P.; Endringer, D.C.; Scherer, R.; Fronza, M. Potential anti-inflammatory, antioxidant and antimicrobial activities of Sambucus australis. Pharm. Biol. 2017, 55, 991-997. [CrossRef]

89. Akinyemi, K.; Mendie, U.; Smith, S.; Oyefolu, A.; Coker, A. Screening of some medicinal plants used in south-west Nigerian traditional medicine for anti-Salmonella typhi activity. J. Herb. Pharmacother. 2005, 5, 45-60. [CrossRef] [PubMed]

90. Franklyne, J.S.; Mukherjee, A.; Chandrasekaran, N. Essential oil micro- and nanoemulsions: Promising roles in antimicrobial therapy targeting human pathogens. Lett. Appl. Microbiol. 2016, 63, 322-334. [CrossRef]

91. Raut, J.S.; Karuppayil, S.M. A status review on the medicinal properties of essential oils. Ind. Crop. Prod. 2014, 62, 250-264. [CrossRef] 
92. Ovais, M.; Zia, N.; Khalil, A.T.; Ayaz, M.; Khalil, A.; Ahmad, I. Nanoantibiotics: Recent Developments and Future Prospects. Front. Clin. Drug Res. Anti. Infect. 2019, 5, 158.

93. Qasim Nasar, M.; Zohra, T.; Khalil, A.T.; Saqib, S.; Ayaz, M.; Ahmad, A.; Shinwari, Z.K. Seripheidium quettense mediated green synthesis of biogenic silver nanoparticles and their theranostic applications. Green Chem. Lett. Rev. 2019, 12, 310-322. [CrossRef]

94. Ovais, M.; Ahmad, I.; Khalil, A.T.; Mukherjee, S.; Javed, R.; Ayaz, M.; Raza, A.; Shinwari, Z.K. Wound healing applications of biogenic colloidal silver and gold nanoparticles: Recent trends and future prospects. Appl. Microbiol. Biotechnol. 2018, 102, 4305-4318. [CrossRef]

95. Ovais, M.; Khalil, A.T.; Islam, N.U.; Ahmad, I.; Ayaz, M.; Saravanan, M.; Shinwari, Z.K.; Mukherjee, S. Role of plant phytochemicals and microbial enzymes in biosynthesis of metallic nanoparticles. Appl. Microbiol. Biotechnol. 2018, 102, 6799-6814. [CrossRef]

96. Ayaz, M.; Ovais, M.; Ahmad, I.; Sadiq, A.; Khalil, A.T.; Ullah, F. Biosynthesized metal nanoparticles as potential Alzheimer's disease therapeutics. In Metal Nanoparticles for Drug Delivery and Diagnostic Applications; Elsevier: Amsterdam, The Netherlands, 2020; pp. 31-42.

97. Elemike, E.; Onwudiwe, D.; Ekennia, A.; Sonde, C.; Ehiri, R. Green Synthesis of Ag/Ag2O Nanoparticles Using Aqueous Leaf Extract of Eupatorium odoratum and Its Antimicrobial and Mosquito Larvicidal Activities. Molecules 2017, 22, 674. [CrossRef]

98. Elemike, E.E.; Onwudiwe, D.C.; Ekennia, A.C.; Ehiri, R.C.; Nnaji, N.J. Phytosynthesis of silver nanoparticles using aqueous leaf extracts of Lippia citriodora: Antimicrobial, larvicidal and photocatalytic evaluations. Mater. Sci. Eng. C Mater. Biol. Appl. 2017, 75, 980-989. [CrossRef]

99. Rashid, M.M.O.; Akhter, K.N.; Chowdhury, J.A.; Hossen, F.; Hussain, M.S.; Hossain, M.T. Characterization of phytoconstituents and evaluation of antimicrobial activity of silver-extract nanoparticles synthesized from Momordica charantia fruit extract. BMC Complement. Altern. Med. 2017, 17, 336. [CrossRef]

100. Zia, M.; Gul, S.; Akhtar, J.; Haq, I.U.; Abbasi, B.H.; Hussain, A.; Naz, S.; Chaudhary, M.F. Green synthesis of silver nanoparticles from grape and tomato juices and evaluation of biological activities. IET Nanobiotechnol. 2017, 11, 193-199. [CrossRef] [PubMed]

101. Balakrishnan, S.; Sivaji, I.; Kandasamy, S.; Duraisamy, S.; Kumar, N.S.; Gurusubramanian, G. Biosynthesis of silver nanoparticles using Myristica fragrans seed (nutmeg) extract and its antibacterial activity against multidrug-resistant (MDR) Salmonella enterica serovar Typhi isolates. Environ. Sci. Pollut. Res. Int. 2017, 24, 14758-14769. [CrossRef] [PubMed]

102. Bettelheim, K. Escherichia coli in the normal flora of humans and animals. In Escherichia Coli: Mechanisms of Virulence; Cambridge University Press: Cambridge, UK, 1997; pp. 85-109.

103. Meng, J.; LeJeune, J.T.; Zhao, T.; Doyle, M.P. Enterohemorrhagic Escherichia coli. In Food Microbiology; American Society of Microbiology: Washington, DC, USA, 2013; pp. 287-309.

104. Prescott, L.M.; Harley, J.P.; Klein, D.A. Microbiology; McGraw-Hill: Boston, MA, USA, 2002; Volume fifth.

105. Johnson, J.K.; Robinson, G.L.; Pineles, L.L.; Ajao, A.O.; Zhao, L.; Albrecht, J.S.; Harris, A.D.; Thom, K.A.; Furuno, J.P. Carbapenem MICs in Escherichia coli and Klebsiella Species Producing Extended-Spectrum beta-Lactamases in Critical Care Patients from 2001 to 2009. Antimicrob. Agents Chemother. 2017, 61. [CrossRef]

106. Lu, Z.; Dockery, C.R.; Crosby, M.; Chavarria, K.; Patterson, B.; Giedd, M. Antibacterial Activities of Wasabi against Escherichia coli O157:H7 and Staphylococcus aureus. Front. Microbiol. 2016, 7, 1403. [CrossRef]

107. Lansky, E.P.; Newman, R.A. Punica granatum (pomegranate) and its potential for prevention and treatment of inflammation and cancer. J. Ethnopharmacol. 2007, 109, 177-206. [CrossRef]

108. Rahmani, A.H.; Alsahli, M.A.; Almatroodi, S.A. Active constituents of pomegranates (Punica granatum) as potential candidates in the management of health through modulation of biological activities. Pharmacogn. J. 2017, 9, 689-695. [CrossRef]

109. Rahimi, H.R.; Arastoo, M.; Ostad, S.N. A Comprehensive Review of Punica granatum (Pomegranate) Properties in Toxicological, Pharmacological, Cellular and Molecular Biology Researches. Iran. J. Pharm. Res. IJPR 2012, 11, 385-400. [PubMed]

110. Mostafa, A.A.; Al-Askar, A.A.; Almaary, K.S.; Dawoud, T.M.; Sholkamy, E.N.; Bakri, M.M. Antimicrobial activity of some plant extracts against bacterial strains causing food poisoning diseases. Saudi J. Biol. Sci. 2018, 25, 361-366. [CrossRef] 
111. Zohra, T.; Ovais, M.; Khalil, A.T.; Qasim, M.; Ayaz, M.; Shinwari, Z.K.; Ahmad, S.; Zahoor, M. Bio-guided profiling and HPLC-DAD finger printing of Atriplex lasiantha Boiss. BMC Complement. Altern. Med. 2019, 19, 4. [CrossRef]

112. Al-Zoreky, N.S. Antimicrobial activity of pomegranate (Punica granatum L.) fruit peels. Int. J. Food Microbiol. 2009, 134, 244-248. [CrossRef]

113. Mahwasane, S.; Middleton, L.; Boaduo, N. An ethnobotanical survey of indigenous knowledge on medicinal plants used by the traditional healers of the Lwamondo area, Limpopo province, South Africa. S. Afr. J. Bot. 2013, 88, 69-75. [CrossRef]

114. Mathabe, M.C.; Nikolova, R.V.; Lall, N.; Nyazema, N.Z. Antibacterial activities of medicinal plants used for the treatment of diarrhoea in Limpopo Province, South Africa. J. Ethnopharmacol. 2006, 105, $286-293$. [CrossRef] [PubMed]

115. Meléndez, P.A.; Capriles, V.A. Antibacterial properties of tropical plants from Puerto Rico. Phytomedicine 2006, 13, 272-276. [CrossRef] [PubMed]

116. Yang, P.C.; Wang, C.S.; An, Z.Y. A murine model of ulcerative colitis: Induced with sinusitis-derived superantigen and food allergen. BMC Gastroenterol. 2005, 5, 6. [CrossRef]

117. Lina, G.; Cozon, G.; Ferrandiz, J.; Greenland, T.; Vandenesch, F.; Etienne, J. Detection of Staphylococcal superantigenic toxins by a CD69-specific cytofluorimetric assay measuring T-cell activation. J. Clin. Microbiol. 1998, 36, 1042-1045. [CrossRef]

118. Llewelyn, M.; Cohen, J. Superantigens: Microbial agents that corrupt immunity. Lancet Infect. Dis. 2002, 2, 156-162. [CrossRef]

119. Letertre, C.; Perelle, S.; Dilasser, F.; Fach, P. Identification of a new putative enterotoxin SEU encoded by the egc cluster of Staphylococcus aureus. J. Appl. Microbiol. 2003, 95, 38-43. [CrossRef]

120. Fueyo, J.M.; Mendoza, M.C.; Rodicio, M.R.; Muniz, J.; Alvarez, M.A.; Martin, M.C. Cytotoxin and pyrogenic toxin superantigen gene profiles of Staphylococcus aureus associated with subclinical mastitis in dairy cows and relationships with macrorestriction genomic profiles. J. Clin. Microbiol. 2005, 43, 1278-1284. [CrossRef]

121. Umeda, K.; Nakamura, H.; Yamamoto, K.; Nishina, N.; Yasufuku, K.; Hirai, Y.; Hirayama, T.; Goto, K.; Hase, A.; Ogasawara, J. Molecular and epidemiological characterization of staphylococcal foodborne outbreak of Staphylococcus aureus harboring seg, sei, sem, sen, seo, and selu genes without production of classical enterotoxins. Int. J. Food Microbiol. 2017, 256, 30-35. [CrossRef]

122. Naz, R.; Ayub, H.; Nawaz, S.; Islam, Z.U.; Yasmin, T.; Bano, A.; Wakeel, A.; Zia, S.; Roberts, T.H. Antimicrobial activity, toxicity and anti-inflammatory potential of methanolic extracts of four ethnomedicinal plant species from Punjab, Pakistan. BMC Complement. Altern. Med. 2017, 17, 302. [CrossRef]

123. Hoekou, Y.P.; Tchacondo, T.; Karou, S.D.; Yerbanga, R.S.; Achoribo, E.; Da, O.; Atakpama, W.; Batawila, K. Therapeutic Potentials of Ethanolic Extract of Leaves of Holarrhena floribunda (G. Don) Dur. and Schinz (Apocynaceae). Afr. J. Tradit. Complement. Altern. Med. 2017, 14, 227-233. [CrossRef] [PubMed]

124. Tamokou, J.D.D.; Tala, M.F.; Wabo, H.K.; Kuiate, J.R.; Tane, P. Antimicrobial activities of methanol extract and compounds from stem bark of Vismia rubescens. J. Ethnopharmacol. 2009, 124, 571-575. [CrossRef] [PubMed]

125. Kuete, V.; Nguemeving, J.R.; Beng, V.P.; Azebaze, A.G.B.; Etoa, F.-X.; Meyer, M.; Bodo, B.; Nkengfack, A.E. Antimicrobial activity of the methanolic extracts and compounds from Vismia laurentii De Wild (Guttiferae). J. Ethnopharmacol. 2007, 109, 372-379. [CrossRef] [PubMed]

126. Idowu, T.O.; Ogundaini, A.O.; Adesanya, S.A.; Onawunmi, G.O.; Osungunna, M.O.; Obuotor, E.M.; Abegaz, B.M. Isolation and Characterization of Chemical Constituents from Chrysophyllum Albidum G. Don-Holl. Stem-Bark Extracts and Their Antioxidant and Antibacterial Properties. Afr. J. Tradit. Complement. Altern. Med. 2016, 13, 182-189. [CrossRef] [PubMed]

127. Coulibaly, K.; Zirihi, G.N.; Guessennd-Kouadio, N.; Oussou, K.R.; Dosso, M. Antibacterial properties studies of trunk barks of Terminalia ivorensis, a commercial and medicinal species on some methicillin-resistant Staphylococci species strains. Afr. Health Sci. 2014, 14, 753-756. [CrossRef]

128. Elegami, A.; El-Nima, E.; El Tohami, M.; Muddathir, A. Antimicrobial activity of some species of the family Combretaceae. Phytother. Res. 2002, 16, 555-561. [CrossRef]

129. Tayel, A.A.; Hussein, H.; Sorour, N.M.; El-Tras, W.F. Foodborne Pathogens Prevention and Sensory Attributes Enhancement in Processed Cheese via Flavoring with Plant Extracts. J. Food Sci. 2015, 80, M2886-M2891. [CrossRef] 
130. Ferhat, M.; Erol, E.; Beladjila, K.A.; Cetintas, Y.; Duru, M.E.; Ozturk, M.; Kabouche, A.; Kabouche, Z. Antioxidant, anticholinesterase and antibacterial activities of Stachys guyoniana and Mentha aquatica. Pharm. Biol. 2017, 55, 324-329. [CrossRef]

131. Zater, H.; Huet, J.; Fontaine, V.; Benayache, S.; Stevigny, C.; Duez, P.; Benayache, F. Chemical constituents, cytotoxic, antifungal and antimicrobial properties of Centaurea diluta Ait. subsp. algeriensis (Coss. \& Dur.) Maire. Asian Pac. J. Trop. Med. 2016, 9, 554-561. [CrossRef]

132. Bouchouka, E.; Djilani, A.; Bekkouche, A. Antibacterial and antioxidant activities of three endemic plants from Algerian Sahara. Acta Sci. Pol. Technol. Aliment. 2012, 11, 61-65.

133. Njeru, S.N.; Obonyo, M.; Nyambati, S.; Ngari, S.; Mwakubambanya, R.; Mavura, H. Antimicrobial and cytotoxicity properties of the organic solvent fractions of Clerodendrum myricoides (Hochst.) R. Br. ex Vatke: Kenyan traditional medicinal plant. J. Intercult Ethnopharmacol. 2016, 5, 226-232. [CrossRef] [PubMed]

134. Wang, J.; Wang, Z.; Wu, R.; Jiang, D.; Bai, B.; Tan, D.; Yan, T.; Sun, X.; Zhang, Q.; Wu, Z. Proteomic Analysis of the Antibacterial Mechanism of Action of Juglone against Staphylococcus aureus. Nat. Prod. Commun. 2016, 11, 825-827. [CrossRef]

135. Lee, Y.S.; Han, S.H.; Lee, S.H.; Kim, Y.G.; Park, C.B.; Kang, O.H.; Keum, J.H.; Kim, S.B.; Mun, S.H.; Seo, Y.S.; et al. The mechanism of antibacterial activity of tetrandrine against Staphylococcus aureus. Foodborne Pathog. Dis. 2012, 9, 686-691. [CrossRef] [PubMed]

136. Wang, H.; Zou, D.; Xie, K.; Xie, M. Antibacterial mechanism of fraxetin against Staphylococcus aureus. Mol. Med. Rep. 2014, 10, 2341-2345. [CrossRef]

137. Kim, Y.S.; Kim, H.; Jung, E.; Kim, J.H.; Hwang, W.; Kang, E.J.; Lee, S.; Ha, B.J.; Lee, J.; Park, D. A novel antibacterial compound from Siegesbeckia glabrescens. Molecules 2012, 17, 12469-12477. [CrossRef]

138. Bajpai, V.K.; Kang, S.C. Antibacterial abietane-type diterpenoid, taxodone from Metasequoia glyptostroboides Miki ex Hu. J. Biosci. 2010, 35, 533-538. [CrossRef] [PubMed]

139. Lee, L.Y.; Shim, J.S.; Rukayadi, Y.; Hwang, J.K. Antibacterial activity of xanthorrhizol isolated from Curcuma xanthorrhiza Roxb. against foodborne pathogens. J. Food Prot. 2008, 71, 1926-1930. [CrossRef]

140. Linde, G.A.; Gazim, Z.C.; Cardoso, B.K.; Jorge, L.F.; Tesevic, V.; Glamoclija, J.; Sokovic, M.; Colauto, N.B. Antifungal and antibacterial activities of Petroselinum crispum essential oil. Genet Mol. Res. 2016, 15. [CrossRef]

141. Tavakoli, H.R.; Mashak, Z.; Moradi, B.; Sodagari, H.R. Antimicrobial Activities of the Combined Use of Cuminum cyminum L. Essential Oil, Nisin and Storage Temperature Against Salmonella typhimurium and Staphylococcus aureus In Vitro. Jundishapur J. Microbiol. 2015, 8, e24838. [CrossRef]

142. Monu, E.A.; David, J.R.; Schmidt, M.; Davidson, P.M. Effect of white mustard essential oil on the growth of foodborne pathogens and spoilage microorganisms and the effect of food components on its efficacy. J. Food Prot. 2014, 77, 2062-2068. [CrossRef] [PubMed]

143. Park, M.J.; Choi, W.S.; Kang, H.Y.; Gwak, K.S.; Lee, G.S.; Jeung, E.B.; Choi, I.G. Inhibitory effect of the essential oil from Chamaecyparis obtusa on the growth of food-borne pathogens. J. Microbiol. 2010, 48, 496-501. [CrossRef]

144. Hale, T.L. Genetic basis of virulence in Shigella species. Microbiol. Mol. Biol. Rev. 1991, 55, $206-224$. [CrossRef]

145. Surawicz, C.M. Mechanisms of diarrhea. Curr. Gastroenterol. Rep. 2010, 12, 236-241. [CrossRef]

146. Mattock, E.; Blocker, A.J. How Do the Virulence Factors of Shigella Work Together to Cause Disease? Front. Cell. Infect. Microbiol. 2017, 7, 64. [CrossRef] [PubMed]

147. Mahboubi, A.; Asgarpanah, J.; Sadaghiyani, P.N.; Faizi, M. Total phenolic and flavonoid content and antibacterial activity of Punica granatum L. var. pleniflora flowers (Golnar) against bacterial strains causing foodborne diseases. BMC Complement. Altern. Med. 2015, 15, 366. [CrossRef]

148. Mahboubi, A.; Kamalinejad, M.; Ayatollahi, A.M.; Babaeian, M. Total Phenolic Content and Antibacterial Activity of Five Plants of Labiatae against Four Foodborne and Some Other Bacteria. Iran. J. Pharm. Res. IJPR 2014, 13, 559-566.

149. van Vuuren, S.F.; Nkwanyana, M.N.; de Wet, H. Antimicrobial evaluation of plants used for the treatment of diarrhoea in a rural community in northern Maputaland, KwaZulu-Natal, South Africa. BMC Complement. Altern. Med. 2015, 15, 53. [CrossRef] 
150. Nasir, M.; Tafess, K.; Abate, D. Antimicrobial potential of the Ethiopian Thymus schimperi essential oil in comparison with others against certain fungal and bacterial species. BMC Complement. Altern. Med. 2015, 15, 260. [CrossRef]

151. Srivastava, U.; Ojha, S.; Tripathi, N.N.; Singh, P. In vitro antibacterial, antioxidant activity and total phenolic content of some essential oils. J. Environ. Biol. 2015, 36, 1329-1336.

152. Hamon, M.; Bierne, H.; Cossart, P. Listeria monocytogenes: A multifaceted model. Nat. Rev. Microbiol. 2006, 4, 423-434. [CrossRef]

153. Portnoy, D.A.; Chakraborty, T.; Goebel, W.; Cossart, P. Molecular determinants of Listeria monocytogenes pathogenesis. Infection and immunity. 1992, 60, 1263. [CrossRef]

154. Gray, M.L.; Killinger, A. Listeria monocytogenes and listeric infections. Bacteriol. Rev. 1966, 30, 309. [CrossRef]

155. Farber, J.M.; Peterkin, P.I. Listeria monocytogenes, a food-borne pathogen. Microbiol. Rev. 1991, 55, 476-511. [CrossRef] [PubMed]

156. Yoon, Y.; Choi, K.H. Antimicrobial activities of therapeutic herbal plants against Listeria monocytogenes and the herbal plant cytotoxicity on Caco-2 cell. Lett. Appl. Microbiol. 2012, 55, 47-55. [CrossRef] [PubMed]

157. Upadhyay, A.; Johny, A.K.; Amalaradjou, M.A.; Ananda Baskaran, S.; Kim, K.S.; Venkitanarayanan, K. Plant-derived antimicrobials reduce Listeria monocytogenes virulence factors in vitro, and down-regulate expression of virulence genes. Int. J. Food Microbiol. 2012, 157, 88-94. [CrossRef]

158. Xu, Y.; Li, G.; Zhang, B.; Wu, Q.; Wang, X.; Xia, X. Tannin-rich pomegranate rind extracts reduce adhesion to and invasion of Caco-2 cells by Listeria monocytogenes and decrease its expression of virulence genes. J. Food Prot. 2015, 78, 128-133. [CrossRef]

159. Raeisi, M.; Tajik, H.; Razavi Rohani, S.M.; Tepe, B.; Kiani, H.; Khoshbakht, R.; Shirzad Aski, H.; Tadrisi, H. Inhibitory effect of Zataria multiflora Boiss. essential oil, alone and in combination with monolaurin, on Listeria monocytogenes. Vet. Res. Forum. 2016, 7, 7-11.

160. Rabiey, S.; Hosseini, H.; Rezaei, M. Use Carum copticum essential oil for controlling the Listeria monocytogenes growth in fish model system. Braz. J. Microbiol. 2014, 45, 89-96. [CrossRef]

161. El Abed, N.; Kaabi, B.; Smaali, M.I.; Chabbouh, M.; Habibi, K.; Mejri, M.; Marzouki, M.N.; Ben Hadj Ahmed, S. Chemical Composition, Antioxidant and Antimicrobial Activities of Thymus capitata Essential Oil with Its Preservative Effect against Listeria monocytogenes Inoculated in Minced Beef Meat. Evid. Based Complement. Altern. Med. 2014, 2014, 152487. [CrossRef]

162. Leite, C.J.; de Sousa, J.P.; Medeiros, J.A.; da Conceicao, M.L.; dos Santos Falcao-Silva, V.; de Souza, E.L. Inactivation of Escherichia coli, Listeria monocytogenes, and Salmonella enteritidis by Cymbopogon citratus D.C. Stapf. Essential Oil in Pineapple Juice. J. Food Prot. 2016, 79, 213-219. [CrossRef]

163. Ngang, J.J.; Nyegue, M.A.; Ndoye, F.C.; Tchuenchieu Kamgain, A.D.; Sado Kamdem, S.L.; Lanciotti, R.; Gardini, F.; Etoa, F.X. Characterization of Mexican coriander (Eryngium foetidum) essential oil and its inactivation of Listeria monocytogenes in vitro and during mild thermal pasteurization of pineapple juice. J. Food Prot. 2014, 77, 435-443. [CrossRef] [PubMed]

164. Poxton, I.R. Other Clostridium spp. In Principles and Practice of Clinical Bacteriology, 2nd ed.; John Wiley \& Sons Ltd.: West Sussex, UK, 2006; pp. 567-574.

165. Sugiyama, H. Clostridium botulinum neurotoxin. Microbiol. Rev. 1980, 44, 419. [CrossRef] [PubMed]

166. Sakaguchi, G. Clostridium botulinum toxins. Pharmacol. Ther. 1982, 19, 165-194. [CrossRef]

167. Doyle, M.P.; Buchanan, R.L. Food Microbiology: Fundamentals and Frontiers; American Society for Microbiology Press: Washington, DC, USA, 2012.

168. Shukla, H.D.; Sharma, S.K. Clostridium botulinum: A bug with beauty and weapon. Crit. Rev. Microbiol. 2005, 31, 11-18. [CrossRef]

169. Nakai, Y.; Pellett, S.; Tepp, W.H.; Johnson, E.A.; Janda, K.D. Toosendanin: Synthesis of the AB-ring and investigations of its anti-botulinum properties (Part II). Bioorganic Med. Chem. 2010, 18, 1280-1287. [CrossRef]

170. Uzal, F.A.; Freedman, J.C.; Shrestha, A.; Theoret, J.R.; Garcia, J.; Awad, M.M.; Adams, V.; Moore, R.J.; Rood, J.I.; McClane, B.A. Towards an understanding of the role of Clostridium perfringens toxins in human and animal disease. Future Microbiol. 2014, 9, 361-377. [CrossRef]

171. Garcia, S.; Araiza, M.; Gomez, M.; Heredia, N. Inhibition of growth, enterotoxin production, and spore formation of Clostridium perfringens by extracts of medicinal plants. J. Food Prot. 2002, 65, 1667-1669. [CrossRef] 
172. De Oliveira, T.L.C.; de Araújo Soares, R.; Ramos, E.M.; das Graças Cardoso, M.; Alves, E.; Piccoli, R.H. Antimicrobial activity of Satureja montana L. essential oil against Clostridium perfringens type A inoculated in mortadella-type sausages formulated with different levels of sodium nitrite. Int. J. Food Microbiol. 2011, 144, 546-555. [CrossRef] [PubMed]

173. David, X.Y.; Zhiyong, H.; Wenyue, W.; Colin, P.; Zhi-cheng, X. The Effects of Berberine on Clostridium perfringens Induced Necrotic Enteritis in Broiler Chickens. Arch. Clin. Microbiol. 2017, 8. [CrossRef]

174. Ahn, Y.; Kwon, J.; Chae, S.; Park, J.; Yoo, J. Growth-inhibitory responses of human intestinal bacteria to extracts of oriental medicinal plants. Microb. Ecol. Health Dis. 1994, 7, 257-261.

175. Bottone, E.J. Bacillus cereus, a volatile human pathogen. Clin. Microbiol. Rev. 2010, 23, 382-398. [CrossRef] [PubMed]

176. Jun, H.; Kim, J.; Bang, J.; Kim, H.; Beuchat, L.R.; Ryu, J.-H. Combined effects of plant extracts in inhibiting the growth of Bacillus cereus in reconstituted infant rice cereal. Int. J. Food Microbiol. 2013, 160, 260-266. [CrossRef] [PubMed]

177. Hamdan, M.; Al-Ismail, K.; Al-Delaimy, K. The antibacterial activity of selected edible plant extracts against Bacillus cereus. Jordan J. Agric. Sci. 2007, 3, 148-155.

178. Silva, A.J.; Benitez, J.A. Vibrio cholerae biofilms and cholera pathogenesis. PLoS Negl. Trop. Dis. 2016, 10, e0004330. [CrossRef] [PubMed]

179. Faruque, S.M.; Albert, M.J.; Mekalanos, J.J. Epidemiology, Genetics, and Ecology of Toxigenic Vibrio cholerae. Microbiol. Mol. Biol. Rev. 1998, 62, 1301-1314. [CrossRef]

180. Sánchez, E.; Heredia, N.; del Camacho-Corona, M.R.; García, S. Isolation, characterization and mode of antimicrobial action against Vibrio cholerae of methyl gallate isolated from Acacia farnesiana. J. Appl. Microbiol. 2013, 115, 1307-1316. [CrossRef]

181. Yamasaki, S.; Asakura, M.; Neogi, S.B.; Hinenoya, A.; Iwaoka, E.; Aoki, S. Inhibition of virulence potential of Vibrio cholerae by natural compounds. Indian J. Med Res. 2011, 133, 232.

182. García, S.; Alarcón, G.; Rodríguez, C.; Heredia, N. Extracts of Acacia farnesiana and Artemisia ludoviciana inhibit growth, enterotoxin production and adhesion of Vibrio cholerae. World J. Microbiol. Biotechnol. 2006, 22, 669-674. [CrossRef]

183. Acharyya, S.; Patra, A.; Bag, P.K. Evaluation of the antimicrobial activity of some medicinal plants against enteric bacteria with particular reference to multi-drug resistant Vibrio cholerae. Trop. J. Pharm. Res. 2009, 8, 231-237. [CrossRef]

184. Lopman, B.A.; Reacher, M.; Gallimore, C.; Adak, G.K.; Gray, J.J.; Brown, D.W. A summertime peak of" winter vomiting disease": Surveillance of noroviruses in England and Wales, 1995 to 2002. BMC Public Health 2003, 3, 13. [CrossRef]

185. Chan, C.M.V.; Chan, C.W.D.; Ma, C.k.; Chan, H.B. Norovirus as cause of benign convulsion associated with gastro-enteritis. J. Paediatr. Child Health 2011, 47, 373-377. [CrossRef] [PubMed]

186. Glass, R.I.; Parashar, U.D.; Estes, M.K. Norovirus Gastroenteritis. N. Engl. J. Med. 2009, 361, $1776-1785$. [CrossRef] [PubMed]

187. Choudhuri, B.S.; Bhakta, S.; Barik, R.; Basu, J.; Kundu, M.; Chakrabati, P. Overexpression and functional characterization of an ABC (ATP-binding cassette) transporter encoded by the genes drrA and drrB of Mycobacterium tuberculosis. J. Bacteriol. 2002, 367, 279-285. [CrossRef] [PubMed]

188. Zhang, X.-F.; Dai, Y.-C.; Zhong, W.; Tan, M.; Lv, Z.-P.; Zhou, Y.-C.; Jiang, X. Tannic acid inhibited norovirus binding to HBGA receptors, a study of 50 Chinese medicinal herbs. Bioorganic Med. Chem. 2012, 20, 1616-1623. [CrossRef] [PubMed]

189. Su, X.; D'Souza, D.H. Grape seed extract for control of human enteric viruses. Appl. Environ. Microbiol. 2011, 77, 3982-3987. [CrossRef]

190. Gilling, D.H.; Kitajima, M.; Torrey, J.R.; Bright, K.R. Mechanisms of antiviral action of plant antimicrobials against murine norovirus. Appl. Environ. Microbiol. 2014, 80, 4898-4910. [CrossRef]

191. Cortez, V.; Meliopoulos, V.A.; Karlsson, E.A.; Hargest, V.; Johnson, C.; Schultz-Cherry, S. Astrovirus biology and pathogenesis. Annu. Rev. Virol. 2017, 4, 327-348. [CrossRef]

192. Téllez, M.; Téllez, A.; Vélez, F.; Ulloa, J. In vitro antiviral activity against rotavirus and astrovirus infection exerted by substances obtained from Achyrocline bogotensis (Kunth) DC.(Compositae). BMC Complement. Altern. Med. 2015, 15, 428. 
193. El-Baz, F.; El-Senousy, W.; El-Sayed, A.; Kamel, M. In vitro antiviral and antimicrobial activities of Spirulina platensis extract. J. Appl. Pharm. Sci. 2013, 3, 52-56.

194. Kudi, A.; Myint, S. Antiviral activity of some Nigerian medicinal plant extracts. J. Ethnopharmacol. 1999, 68, 289-294. [CrossRef]

195. Cuthbert, J.A. Hepatitis A: Old and new. Clin. Microbiol. Rev. 2001, 14, 38-58. [CrossRef] [PubMed]

196. Seo, D.J.; Lee, M.; Jeon, S.B.; Park, H.; Jeong, S.; Lee, B.-H.; Choi, C. Antiviral activity of herbal extracts against the hepatitis A virus. Food Control 2017, 72, 9-13. [CrossRef]

197. Abd-Elshafy, D.N. Effect of methanolic-extracted green tea on hepatitis A virus and its usage in clearing the virus from drinking Water. J. Virol. Sci. 2018, 3, 58-67.

198. Ogilvie, I.; Khoury, H.; El Khoury, A.C.; Goetghebeur, M.M. Burden of rotavirus gastroenteritis in the pediatric population in Central and Eastern Europe: Serotype distribution and burden of illness. Hum. Vaccines 2011, 7, 523-533. [CrossRef]

199. Grimwood, K.; Lambert, S.B.; Milne, R.J. Rotavirus infections and vaccines. Pediatr. Drugs 2010, 12, $235-256$. [CrossRef]

200. Cecílio, A.B.; de Faria, D.B.; de Carvalho Oliveira, P.; Caldas, S.; de Oliveira, D.A.; Sobral, M.E.G.; Duarte, M.G.R.; de Souza Moreira, C.P.; Silva, C.G.; de Almeida, V.L. Screening of Brazilian medicinal plants for antiviral activity against rotavirus. J. Ethnopharmacol. 2012, 141, 975-981. [CrossRef]

201. Knipping, K.; Garssen, J.; van't Land, B. An evaluation of the inhibitory effects against rotavirus infection of edible plant extracts. Virol. J. 2012, 9, 137. [CrossRef]

202. Sun, Y.; Gong, X.; Tan, J.Y.; Kang, L.; Li, D.; Yang, J.; Du, G. In vitro Antiviral Activity of Rubia cordifolia Aerial Part Extract against Rotavirus. Front. Pharmacol. 2016, 7, 308. [CrossRef]

203. Mohamed, S.; Mamdouh, E.; Adel, M.; Samy, M.; Nagwa, E. Antiviral activity of Bauhinia variegata extracts against rotavirus in vitro. Curr. Sci. Int. 2014, 3, 172-178.

204. Shaheen, M.; Mostafa, S.; El-Esnawy, N. Anti-Rotaviral Effects of Calliandra haematocephala Leaf Extracts In-vitro and In-vivo. J. Virol. Antivir. Res. 2015, 4, 1-7. [CrossRef]

205. Kawahara, T.; Tomono, T.; Hamauzu, Y.; Tanaka, K.; Yasui, H. Inhibitory effect of a hot-water extract of leaves of Japanese big-leaf magnolia (Magnolia obovata) on rotavirus-induced diarrhea in mouse pups. Evid. Based Complement. Altern. Med. 2014, 2014, 365831. [CrossRef] [PubMed]

206. Farthing, M.J. Giardiasis. Gastroenterol. Clin. 1996, 25, 493-515. [CrossRef]

207. Derda, M.; Hadaś, E. The use of phytotherapy in diseases caused by parasitic protozoa. Acta Parasitol. 2015, 60, 1-8. [CrossRef]

208. Hawrelak, J. Giardiasis: Pathophysiology and management. Altern. Med. Rev. 2003, 8, 129-142.

209. Phillipson, J.D.; Wright, C.W.; Kirby, G.C.; Warhurst, D.C. Tropical plants as sources of antiprotozoal agents. In Phytochemical Potential of Tropical Plants; Springer: New York, NY, USA, 1993; pp. 1-40.

210. Ross, I. Medicinal Plants of the World: Chemical Constituents, Traditional and Modern Medicinal Uses; Humana Press: Totowa, NJ, USA, 2002; pp. 25-63.

211. Soffar, S.; Mokhtar, G. Evaluation of the antiparasitic effect of aqueous garlic (Allium sativum) extract in hymenolepiasis nana and giardiasis. J. Egypt. Soc. Parasitol. 1991, 21, 497-502.

212. Ankri, S.; Mirelman, D. Antimicrobial properties of allicin from garlic. Microbes Infect. 1999, 1, $125-129$. [CrossRef]

213. Jiménez, J.; Uzcanga, G.; Zambrano, A.; Di Prisco, M.; Lynch, N. Identification and partial characterization of excretory/secretory products with proteolytic activity in Giardia intestinalis. J. Parasitol. 2000, 86, 859-862. [CrossRef]

214. Frawley, D.; Lad, V. The Yoga of Herbs: An Ayurvedic Guide to Herbal Medicine; Lotus Press: Twin Lakeswi, Kenosha County, WI, USA, 1986; pp. 180-182.

215. Tripathi, D.; Gupta, N.; Lakshmi, V.; Saxena, K.; Agrawal, A. Antigiardial and immunostimulatory effect of Piper longum on giardiasis due to Giardia lamblia. Phytother. Res. 1999, 13, 561-565. [CrossRef]

216. Agarwal, A.; Singh, M.; Gupta, N.; Saxena, R.; Puri, A.; Verma, A.; Saxena, R.; Dubey, C.; Saxena, K. Management of giardiasis by an immuno-modulatory herbal drug Pippali Rasayana. J. Ethnopharmacol. 1994, 44, 143-146. [CrossRef]

217. Agrawal, A.; Tripathi, D.; Sahai, R.; Gupta, N.; Saxena, R.; Puri, A.; Singh, M.; Misra, R.; Dubey, C.; Saxena, K. Management of Giardiasis by a herbal drug 'Pippali Rasayana': A clinical study. J. Ethnopharmacol. 1997, 56, 233-236. [CrossRef] 
218. Miyares, C.; Hollands, I.; Castaneda, C.; Gonzalez, T.; Fragoso, T.; Curras, R.; Soria, C. Clinical trial with a preparation based on propolis"propolisina" in human giardiasis. Acta Gastroenterol. Latinoam. 1987, 18, 195-201.

219. Snow, J.M. Hydrastis canadensis L. (Ranunculaceae). Protoc. J. Bot. Med. 1997, 2, 25-30.

220. Willard, T. The Wild Rose Scientific Herbal; Wild Rose College of Natural Healing: Calgary, AB, Canada, 1991; pp. 24-29.

221. Kaneda, Y.; Torii, M.; Tanaka, T.; Aikawa, M. In vitro effects of berberine sulphate on the growth and structure of Entamoeba histolytica, Giardia lamblia and Trichomonas vaginalis. Ann. Trop. Med. Parasitol. 1991, 85, 417-425. [CrossRef] [PubMed]

222. Choudhry, V.; Sabir, M.; Bhide, V. Berberine in giardiasis. Indian Pediatr. 1972, 9, 143. [PubMed]

223. Gupte, S. Use of berberine in treatment of giardiasis. Am. J. Dis. Child. 1975, 129, 866. [CrossRef]

224. Kaneda, Y.; Tanaka, T.; Saw, T. Effects of berberine, a plant alkaloid, on the growth of anaerobic protozoa in axenic culture. Tokai J. Exp. Clin. Med. 1990, 15, 417-423.

225. Calzada, F.; Meckes, M.; Cedillo-Rivera, R. Antiamoebic and antigiardial activity of plant flavonoids. Planta Med. 1999, 65, 78-80. [CrossRef]

226. Cai, Y.; Evans, F.; Roberts, M.; Phillipson, J.; Zenk, M.; Gleba, Y. Polyphenolic compounds from Croton lechleri. Phytochemistry 1991, 30, 2033-2040. [CrossRef]

227. Blumenthal, M.; Goldberg, A.; Brinckmann, J. Herbal Medicine: Expanded Commission E Monographs; Integrative Medicine Communications: Austintx, TX, USA, 2000; pp. 413-417.

228. Ponce-Macotela, M.; Navarro-Alegria, I.; Martinez-Gordillo, M.; Alvarez-Chacon, R. In vitro effect against Giardia of 14 plant extracts. Rev. Investig. Clin. Organo Hosp. Enferm. Nutr. 1993, 46, 343-347.

229. Barbosa, E.; Calzada, F.; Campos, R. In vivo antigiardial activity of three flavonoids isolated of some medicinal plants used in Mexican traditional medicine for the treatment of diarrhea. J. Ethnopharmacol. 2007, 109, 552-554. [CrossRef]

230. Orozco, E.; Pérez, D.; Gómez, M.; Ayala, P. Multidrug resistance in Entamoeba histolytica. Parasitol. Today 1995, 11, 473-475. [CrossRef]

231. Bruckner, D.A. Amebiasis. Clin. Microbiol. Rev. 1992, 5, 356-369. [CrossRef] [PubMed]

232. Tengku, S.; Norhayati, M. Review Paper Public health and clinical importance of amoebiasis in Malaysia: A review. Trop. Biomed. 2011, 28, 194-222.

233. Kammanadiminti, S.J. Early Interactions between Entamoeba histolytica and Mucosal Cells; McGill University Libraries: Montreal, QC, Canada, 2006.

234. Otshudi, A.L.; Vercruysse, A.; Foriers, A. Contribution to the ethnobotanical, phytochemical and pharmacological studies of traditionally used medicinal plants in the treatment of dysentery and diarrhoea in Lomela area, Democratic Republic of Congo (DRC). J. Ethnopharmacol. 2000, 71, 411-423. [CrossRef]

235. Taylor, M.; Pillai, G.; Kvalsvig, J. Targeted chemotherapy for parasite infestations in rural black preschool children. S. Afr. Med. J. 1995, 85, 870-874.

236. Swetman, S.C. Martindale. In: The Complete Drug Reference 33th ed. Pharm. Presslondon 2002, 594.

237. Kapoor, K.; Chandra, M.; Nag, D.; Paliwal, J.; Gupta, R.; Saxena, R. Evaluation of metronidazole toxicity: A prospective study. Int. J. Clin. Pharmacol. Res. 1998, 19, 83-88.

238. Azam, A.; Agarwal, S. Targeting Amoebiasis: Status and developments. Curr. Bioact. Compd. 2007, 3, 121-133. [CrossRef]

239. Ayaz, M.; Junaid, M.; Ullah, F.; Sadiq, A.; Ovais, M.; Ahmad, W.; Zeb, A. Chemical profiling, antimicrobial and insecticidal evaluations of Polygonum hydropiper L. BMC Complement. Altern. Med. 2016, 16, 502. [CrossRef]

240. Ahmad, S.; Ullah, F.; Ayaz, M.; Sadiq, A.; Imran, M. Antioxidant and anticholinesterase investigations of Rumex hastatus D. Don: Potential effectiveness in oxidative stress and neurological disorders. Biol. Res. 2015, 48, 1-8. [CrossRef]

241. Ayaz, M.; Junaid, M.; Ullah, F.; Sadiq, A.; Subhan, F.; Khan, M.A.; Ahmad, W.; Ali, G.; Imran, M.; Ahmad, S. Molecularly characterized solvent extracts and saponins from Polygonum hydropiper L show high anti-angiogenic, anti-tumor, brine shrimp and fibroblast NIH/3T3 cell line cytotoxicity. Front. Pharmacol. 2016, 7, 74. [CrossRef]

242. Zeb, A.; Ahmad, S.; Ullah, F.; Ayaz, M.; Sadiq, A. Anti-nociceptive activity of ethnomedicinally important analgesic plant Isodon rugosus Wall. ex Benth: Mechanistic study and identifications of bioactive compounds. Front. Pharmacol. 2016, 7, 200. [CrossRef] 
243. Gillin, F.; Reiner, D.; Suffness, M. Bruceantin, a potent amoebicide from a plant, Brucea antidysenterica. Antimicrob. Agents Chemother. 1982, 22, 342-345. [CrossRef]

244. Sharma, G.; Bhutani, K. Plant based amoebicidal activity of parthenin isolated from Parthenium hysterophorus. Planta Med. 1987, 2, 120-122.

245. Wright, C.; O'neill, M.; Phillipson, J.; Warhurst, D. Use of microdilution to assess in vitro antiamoebic activities of Brucea javanica fruits, Simarouba amara stem, and a number of quassinoids. Antimicrob. Agents Chemother. 1988, 32, 1725-1729. [CrossRef]

246. Wright, C.; Allen, D.; Cai, Y.; Phillipson, J.; Said, I.; Kirby, G.; Warhurst, D. In vitro antiamoebic and antiplasmodial activities of alkaloids isolated from Alstonia angustifolia roots. Phytother. Res. 1992, 6, 121-124. [CrossRef]

247. Cimanga, R.; Kambu, K.; Tona, L.; Hermans, N.; Apers, S.; Totte, J.; Pieters, L.; Vlietinck, A. Cytotoxicity and in vitro susceptibility of Entamoeba histolytica to Morinda morindoides leaf extracts and its isolated constituents. J. Ethnopharmacol. 2006, 107, 83-90. [CrossRef]

248. Tona, L.; Kambu, K.; Ngimbi, N.; Cimanga, K.; Vlietinck, A. Antiamoebic and phytochemical screening of some Congolese medicinal plants. J. Ethnopharmacol. 1998, 61, 57-65. [CrossRef]

249. Sohni, Y.R.; Kaimal, P.; Bhatt, R.M. The antiamoebic effect of a crude drug formulation of herbal extracts against Entamoeba histolytica in vitro and in vivo. J. Ethnopharmacol. 1995, 45, 43-52. [CrossRef]

250. Calzada, F.; Yepez-Mulia, L.; Tapia-Contreras, A.; Bautista, E.; Maldonado, E.; Ortega, A. Evaluation of the antiprotozoal activity of neo-clerodane type diterpenes from Salvia polystachya against Entamoeba histolytica and Giardia lamblia. Phytother. Res. 2010, 24, 662-665.

251. Calzada, F.; Yépez-Mulia, L.; Aguilar, A. In vitro susceptibility of Entamoeba histolytica and Giardia lamblia to plants used in Mexican traditional medicine for the treatment of gastrointestinal disorders. J. Ethnopharmacol. 2006, 108, 367-370. [CrossRef]

252. Calzada, F.; Cervantes-Martínez, J.A.; Yépez-Mulia, L. In vitro antiprotozoal activity from the roots of Geranium mexicanum and its constituents on Entamoeba histolytica and Giardia lamblia. J. Ethnopharmacol. 2005, 98, 191-193. [CrossRef]

253. Alanís, A.D.; Calzada, F.; Cedillo-Rivera, R.; Meckes, M. Antiprotozoal activity of the constituents of Rubus coriifolius. Phytother. Res. 2003, 17, 681-682. [CrossRef]

254. Kijlstra, A.; Jongert, E. Control of the risk of human toxoplasmosis transmitted by meat. Int. J. Parasitol. 2008, 38, 1359-1370. [CrossRef]

255. Jones, J.L.; Dubey, J. Foodborne toxoplasmosis. Clin. Infect. Dis. 2012, 55, 845-851. [CrossRef]

256. Choi, W.-Y.; Nam, H.-W.; Kwak, N.-H.; Huh, W.; Kim, Y.-R.; Kang, M.-W.; Cho, S.-Y.; Dubey, J. Foodborne outbreaks of human toxoplasmosis. J. Infect. Dis. 1997, 175, 1280-1282. [CrossRef]

257. Jones, J.L.; Hanson, D.L.; Dworkin, M.S.; Alderton, D.L.; Fleming, P.L.; Kaplan, J.E.; Ward, J. Surveillance for AIDS-defining opportunistic illnesses, 1992-1997. Arch. Dermatol. 1999, 135, 897-902. [CrossRef]

258. Gkogka, E.; Reij, M.W.; Havelaar, A.H.; Zwietering, M.H.; Gorris, L.G. Risk-based estimate of effect of foodborne diseases on public health, Greece. Emerg. Infect. Dis. 2011, 17, 1581. [CrossRef]

259. Youn, H.; Lakritz, J.; Kim, D.; Rottinghaus, G.; Marsh, A. Anti-protozoal efficacy of medicinal herb extracts against Toxoplasma gondii and Neospora caninum. Vet. Parasitol. 2003, 116, 7-14. [CrossRef]

260. Wright, C.W.; Anderson, M.M.; Allen, D.; Phillipson, J.D.; Kirby, G.C.; Warhurst, D.C.; Chang, H.R. Quassinoids exhibit greater selectivity against Plasmodium falciparum than against Entamoeba histolytica, Giardia intestinalis or Toxoplasma gondii in vitro. J. Eukaryot. Microbiol. 1993, 40, 244-246. [CrossRef] [PubMed]

261. Choi, K.-M.; Gang, J.; Yun, J. Anti-Toxoplasma gondii RH strain activity of herbal extracts used in traditional medicine. Int. J. Antimicrob. Agents 2008, 32, 360-362. [CrossRef]

262. Vanathy, K.; Parija, S.C.; Mandal, J.; Hamide, A.; Krishnamurthy, S. Cryptosporidiosis: A mini review. Trop. Parasitol. 2017, 7, 72-80.

263. Checkley, W.; White, A.C., Jr.; Jaganath, D.; Arrowood, M.J.; Chalmers, R.M.; Chen, X.-M.; Fayer, R.; Griffiths, J.K.; Guerrant, R.L.; Hedstrom, L. A review of the global burden, novel diagnostics, therapeutics, and vaccine targets for cryptosporidium. Lancet Infect. Dis. 2015, 15, 85-94. [CrossRef]

264. Teichmann, K.; Kuliberda, M.; Schatzmayr, G.; Pacher, T.; Zitterl-Eglseer, K.; Joachim, A.; Hadacek, F. In vitro inhibitory effects of plant-derived by-products against Cryptosporidium parvum. Parasite 2016, $23,41$. [CrossRef] 
265. Al-Jboori, A.H.; Al-Alousi, T.I.; Obiad, H.M. The in vivo effect of some medicinal plant extracts on Cryptosporidium parasite. J. Univ. Anbar Pure Sci. 2012, 6, 15-26.

266. Almoradie, A.M.; Angeles, R.J.; Beltran, E.V.; Ugali, M.; Valles, N.S.; Los Banos, Z.D.; Mahboob, T.; Barusrux, S.; Nissapatorn, V. Cryptosporicidal Activity of Plant Extracts against Cryptosporidium parvum and Cryptosporidium hominis. Asian J. Pharmacogn. 2018, 2, 22-31.

267. Khater, M.M.; El-Sayed, S.H.; Yousof, H.-A.S.; Mahmoud, S.S.; El-Dib, N.; El-Badry, A.A. Anti-Cryptosporidium efficacy of Olea europaea and Actinidia deliciosa in a neonatal mouse model. Kasr Al Ainy Med J. 2017, 23, 32-37. [CrossRef]

268. Saritha, K.; Rajesh, A.; Manjulatha, K.; Setty, O.H.; Yenugu, S. Mechanism of antibacterial action of the alcoholic extracts of Hemidesmus indicus (L.) R. Br. ex Schult, Leucas aspera (Wild.), Plumbago zeylanica L., and Tridax procumbens (L.) R. Br. ex Schult. Front. Microbiol. 2015, 6, 577. [CrossRef]

269. Yadav, A.K.; Saraswat, S.; Sirohi, P.; Rani, M.; Srivastava, S.; Singh, M.P.; Singh, N.K. Antimicrobial action of methanolic seed extracts of Syzygium cumini Linn. on Bacillus subtilis. AMB Express 2017, 7, 196. [CrossRef]

270. Chandar, B.; Poovitha, S.; Ilango, K.; MohanKumar, R.; Parani, M. Inhibition of New Delhi Metallo- $\beta$-Lactamase 1 (NDM-1) producing Escherichia coli IR-6 by selected plant extracts and their synergistic actions with antibiotics. Front. Microbiol. 2017, 8, 1580. [CrossRef]

271. Ono, K.; Nakane, H.; Fukushima, M.; Chermann, J.-C.; Barré-Sinoussi, F. Inhibition of reverse transcriptase activity by a flavonoid compound, 5,6,7-trihydroxyflavone. Biochem. Biophys. Res. Commun. 1989, 160, 982-987. [CrossRef]

272. Brinkworth, R.I.; Stoermer, M.J.; Fairlie, D.P. Flavones are inhibitors of HIV-1 proteinase. Biochem. Biophys. Res. Commun. 1992, 188, 631-637. [CrossRef]

273. Gonelimali, F.D.; Lin, J.; Miao, W.; Xuan, J.; Charles, F.; Chen, M.; Hatab, S.R. Antimicrobial properties and mechanism of action of some plant extracts against food pathogens and spoilage microorganisms. Front. Microbiol. 2018, 9, 1639. [CrossRef]

274. Trombetta, D.; Castelli, F.; Sarpietro, M.G.; Venuti, V.; Cristani, M.; Daniele, C.; Saija, A.; Mazzanti, G.; Bisignano, G. Mechanisms of antibacterial action of three monoterpenes. Antimicrob. Agents Chemother. 2005, 49, 2474-2478. [CrossRef]

275. Alexopoulos, A.; Plessas, S.; Kimbaris, A.; Varvatou, M.; Mantzourani, I.; Fournomiti, M. Mode of antimicrobial action of Origanum vulgare essential oil against clinical pathogens. Curr. Res. Nutr. Food Sci. J. 2017, 5, 109-115. [CrossRef]

276. Faleiro, M. The mode of antibacterial action of essential oils. Sci. Against Microb. Pathog. Commun. Curr. Res. Technol. Adv. 2011, 2, 1143-1156.

277. Sledz, W.; Los, E.; Paczek, A.; Rischka, J.; Motyka, A.; Zoledowska, S.; Piosik, J.; Lojkowska, E. Antibacterial activity of caffeine against plant pathogenic bacteria. Acta Biochim. Pol. 2015, 62, 605-612. [CrossRef]

278. Saad, N.Y.; Muller, C.D.; Lobstein, A. Major bioactivities and mechanism of action of essential oils and their components. Flavour Fragr. J. 2013, 28, 269-279. [CrossRef]

279. Cushnie, T.T.; Cushnie, B.; Lamb, A.J. Alkaloids: An overview of their antibacterial, antibiotic-enhancing and antivirulence activities. Int. J. Antimicrob. Agents 2014, 44, 377-386. [CrossRef]

280. Awasthi, L.; Verma, H.; Kluge, S. A Possible mechanism of action for the inhibition of plant viruses by an antiviral glycoprotein isolated from Boerhaavia diffusa roots. Virol. Antivir. Res. 2016, 2016. [CrossRef]

281. Ngan, L.T.M.; Jang, M.J.; Kwon, M.J.; Ahn, Y.J. Antiviral activity and possible mechanism of action of constituents identified in Paeonia lactiflora root toward human rhinoviruses. PLoS ONE 2015, 10, e0121629. [CrossRef] [PubMed]

282. Idriss, M.T.; Suliman, M.M.; Khongwichit, S.; Tongluan, N.; Smith, D.R.; Abdurahman, N.; Elnima, A.I. Antiviral activity and possible mechanisms of action of Aristolochia bracteolate against influenza A virus. Microbiol. Curr. Res. 2017, 1, 22.

283. Lecoin, M.O.P. Mechanism of action of antiviral compounds isolated from plants: HIV virus as a model. Univ. Tor. Repos. 2008, va07012.

284. Aziz, Q.; Doré, J.; Emmanuel, A.; Guarner, F.; Quigley, E. Gut microbiota and gastrointestinal health: Current concepts and future directions. Neurogastroenterol. Motil. 2013, 25, 4-15. [CrossRef] [PubMed]

285. Robinson, C.J.; Young, V.B. Antibiotic administration alters the community structure of the gastrointestinal microbiota. Gut Microbes 2010, 1, 279-284. [CrossRef] [PubMed] 
286. Zweifel, C.; Stephan, R. Spices and herbs as source of Salmonella-related foodborne diseases. Food Res. Int. 2012, 45, 765-769. [CrossRef]

287. Kim, M.; Zahn, M.; Reporter, R.; Askar, Z.; Green, N.; Needham, M.; Terashita, D. Outbreak of foodborne botulism associated with prepackaged pouches of liquid herbal tea. Open Forum. Infect. Dis. 2019, 6. [CrossRef]

288. Farkas, J. Irradiation as a method for decontaminating food: A review. Int. J. Food Microbiol. 1998, 44, 189-204. [CrossRef]

289. Pelaez, F. The historical delivery of antibiotics from microbial natural products-Can history repeat? Biochem. Pharmacol. 2006, 71, 981-990. [CrossRef]

290. Cowan, M.M. Plant products as antimicrobial agents. Clin. Microbiol. Rev. 1999, 12, 564-582. [CrossRef]

291. Ulrich-Merzenich, G.S. Combination screening of synthetic drugs and plant derived natural products-Potential and challenges for drug development. Synergy 2014, 1, 59-69. [CrossRef]

(C) 2020 by the authors. Licensee MDPI, Basel, Switzerland. This article is an open access article distributed under the terms and conditions of the Creative Commons Attribution (CC BY) license (http://creativecommons.org/licenses/by/4.0/). 